\title{
THE ORAL CORPORA IN CATALAN AND RESEARCH INTO CASUAL CATALAN: THE CORPORA OF CONVERSATION AND FUNCTIONAL VARIETIES OF THE CORPUS DE CATALÀ CONTEMPORANI DE LA UNIVERSITAT DE BARCELONA (CCCUB)*
}

\author{
ELS CORPUS ORALS I EN CATALÀ I EL CATALÀ CORRENT: \\ ELS CORPUS DE CONVERSA I DE VARIETATS FUNCIO- \\ NALS DEL CORPUS DEL CATALÀ CONTEMPORANI \\ DE LA UNIVERSITAT DE BARCELONA (CCCUB)
}

\author{
Lluís Payrató \& Neus Nogué \\ Universitat de Barcelona \\ payrató@ub.edu / nnogue@ub.edu
}

Abstract: The aim of this study is to present a set of corpora of casual Catalan (especially oral and colloquial) gathered together in the VARCOM and PRAGMAESTIL projects carried out over the past twenty years at the University of Barcelona. The research has been conducted by the Grup d'Estudi de la Variació (GEV-UB), in particular by the Grup d'Estudis de Pragmàtica i Anàlisi del Discurs (GrEPAD). This paper reviews an oral corpus of colloquial conversation (COC, 2002), an oral corpus of registers (COR, 2004) and an audiovisual oral corpus of textual varieties (CAP, 2008). In the CAP, for the first time the images of the interlocutors are shown as they speak, alongside the transcribed texts. This paper focuses on the qualitative and research-oriented nature of these corpora. The final part of the text underlines the research possibilities that the corpora offer and also highlights the gaps remaining in the field of corpus linguistics applied to Catalan and its oral varieties.

Key words: corpus, Catalan, language varieties, oral language, applied linguistics.

Resum: Aquest treball pretén exposar el conjunt de corpus i de recerques que s'han elaborat al llarg de diferents projectes promoguts amb l'objectiu de constituir corpus representatius del català corrent (sobretot oral i col-loquial). Els projectes a què es fa referència (VARCOM i PRAGMAESTIL)

(*) This study received funding from the grant 2017 SGR 942. 
s'han dut a terme des de final del segle xx i des de la Universitat de Barcelona, més en concret amb la feina desenvolupada per diferents subgrups del Grup d'Estudi de la Variació (GEV-UB), en particular pel Grup d'Estudis de Pragmàtica i Anàlisi del Discurs (GrEPAD). El treball revisa en especial un corpus oral de conversa col-loquial (COC, 2002), un corpus oral de registres (COR, 2004) i un corpus oral audiovisual de gèneres textuals (CAP, 2008), en què per primera vegada se suma, a la veu paral-lelitzada amb els textos transcrits, la imatge dels interlocutors. El present treball incideix en especial en el caràcter volgudament qualitatiu i orientat a la recerca d'aquests corpus, $i$ alhora en les possibilitats d'investigació que ofereixen i en les mancances que encara són prou evidents en l'àmbit de la lingüística de corpus aplicada al català i a les seves varietats orals.

Paraules clau: corpus, català, varietats lingüístiques, llengua oral, lingüística aplicada.

$\cos \cos$

\section{INTRODUCTION.THEVARCOMANDTHE PRAGMAESTIL PROJECTS AS RESEARCH BACKGROUND}

The Corpus de Català Contemporani de la Universitat de Barcelona (CCCUB) was created as the initial phase of the research on language variation and discourse styles developed in the VARCOM and the PRAGMAESTIL projects.

VARCOM is an abbreviation of "Variation, multimodal communication and multilingualism: discursive styles and linguistic consciousness in the production of oral texts». ${ }^{1}$ The specific goals of VARCOM were to analyze the following aspects:

(I) Design of discourse style typologies in multilingual speakers including verbal and non-verbal (sub)categories.

(2) Contrastive analysis of (non-)verbal stylistic and expressive resources used in oral texts in various formats (narration, description, exposition, argumentation, instruction).

(3) Description of synchronization and interaction mechanisms between communicative modalities (verbal, vocal and non-verbal).

I. The project was supported by the Spanish Ministry of Science and Technology, BFF200I-3866, 20022004. The members of the VARCOM research group were Lluís Payrató (coordinator), Núria Alturo, Francesc Bernat, Josep Besa, Emili Boix, David Casals, Mireia Galindo, Àngels Massip, Neus Nogué, Marta Payà, Joan Solà, F. Xavier Vila, M. Pilar Cadena, Marta Fernández-Villanueva and Oliver Strunk (Universitat de Barcelona), Pilar Prieto (Universitat Autònoma de Barcelona, now Universitat Pompeu Fabra), Miquel Pueyo and Salomé Ribes (Universitat de Lleida), and Juan Pablo Mora (Universidad de Sevilla). 
(4) Study of language awareness in multilingual speakers and their expectations about multilingualism in personal and professional domains.

(5) Analysis of factors that determine the variation in discourse styles in the oral production of multilingual speakers (Catalan, Spanish, and English).

PRAGMAESTIL is an abbreviation of «Pragmatics, style and identities: analysis of verbal and non-verbal properties in multilingual speaker discourse». ${ }^{2}$ Understanding style as a manifestation of the individual identity that becomes concrete in the contextualized production of texts, the main goal of the PRAGMAESTIL project was to analyze some of the most significant aspects in the intralinguistic (in Catalan) and interlinguistic (in Catalan, Spanish, English/German) construction of discursive styles by a selected group of multilingual speakers. Informants were, on the one hand, bilingual Catalan-Spanish speakers with one of the two languages as their Li and family language and, on the other, speakers raised in bilingual homes, all of whom have knowledge of English as L3.

From the dual perspective described above, the PRAGMAESTIL project specifically aims to determine the style types constructed in relation to a standard typology (particularly according to standard text types: narrative, descriptive, expository, argumentative and directive) and to establish the types constructed from categories proposed during the analysis. The specific goals of PRAGMAESTIL were to analyze the following aspects:

(I) Logico-semantic or argumentative connectors and pragmatic connectors.

(2) Thematic textual progression in relation to text structure and type (narrative, descriptive, expository, argumentative and directive).

(3) Verbal and non-verbal expression of deictic elements (person, space, time, and manner) and of the categories related to facts/actions, statements/questions and spatial references.

2. The project was also supported by the Spanish Ministry of Science and Technology, HUM2005-01936/ FILO, 2006-2008. The members of the PRAGMAESTIL research group were Lluís Payrató (coordinator), Núria Alturo, Josep Besa, Òscar Bladas, Marta Fernández-Villanueva, Jaume Fitó, Joseph Hilferty, Neus Nogué, Juli Palou, Joan Solà, Katrin Schmidt, and Oliver Strunk (Universitat de Barcelona), Ignasi Clemente (University of California, Los Angeles; now Hunter College, New York), M. Josep Cuenca (Universitat de València), Montserrat González, and Montserrat Ribas (Universitat Pompeu Fabra), M. Josep Marín (Universitat Politècnica de València, now Universitat de València), Marta Payà (Parliament of Catalonia), and Salomé Ribas (Universitat de Lleida). 
Lluís Payrató \& Neus Nogué

The oral corpora in Catalan and research into casual Catalan:

the corpora of conversation and functional varieties of the CCCUB

(4) Idiolectal markers of speaker identity (lexical selection, construction and syntactic complexity, cohesion formulas, degree of assertiveness, involvement, formality and politeness, among other factors).

\section{THE CORPUS DE CATALÀ CONTEMPORANI DE LA UNIVERSITAT DE BARCELONA (CCCUB)}

The "corpus of contemporary Catalan of the University of Barcelona» (CCCUB) is the result of several projects added to VARCOM and PRAGMAESTIL. Its aim is to collect, transcribe, publish and analyse a corpus of contemporary spoken and written Catalan. ${ }^{3}$

The CCCUB covers a number of geographical, sociocultural, and functional varieties of current Catalan. It has been designed as a set of interconnected modules, each one focusing on a particular dimension of linguistic variation. While some of these modules have already been completed, and already are available for research, others are still in process.

The module covering geographical variation (Corpus Oral Dialectal, COD) has compiled morphological and textual data from fieldwork carried out at 86 locations throughout the Catalan speaking area. The data include 403,766 morphophonological forms, and 543 recorded samples of casual speech, each lasting Io minutes (vid. $<$ http://www.ub.edu/cccub/corpusoraldialectal-cod.html>).

The sociocultural module (Corpus Oral Social, COS, vid. Boix-Fuster et al. 2006) is designed to contain 78 face-to-face interviews, and constitutes a sample of the social varieties currently spoken in the area of Barcelona. Some of the informants are Catalan speakers married to Spanish speakers, which gives additional evidence for language contact studies.

An overview of functional variation is obtained by means of a corpus of registers (Corpus Oral de Registres, COR). Moreover, some specific functional varieties have received particular attention: casual speech (Corpus Oral de Conversa Col-loquial, COC), oral publicity (Corpus Oral de Publicitat, COP), radio newscasting (Corpus

3. Members of the original CCCUB Project were Núria Alturo, Òscar Bladas, Emili Boix, Esteve Clua, Mireia Galindo, M. Rosa Lloret, Mar Massanell, Anna Oller, Marta Payà, Lluís Payrató, M. Pilar Perea, Clàudia Pons, Marta Torres, Joaquim Viaplana, F. Xavier Vila (Universitat de Barcelona) i Amadeu Viana (Universitat de Lleida). 
d'Informatius Orals, CIO), and written media discourse (Corpus Escrit del Català Actual, CECA).

The whole corpus and the organization of these modules can be seen in Figure I.

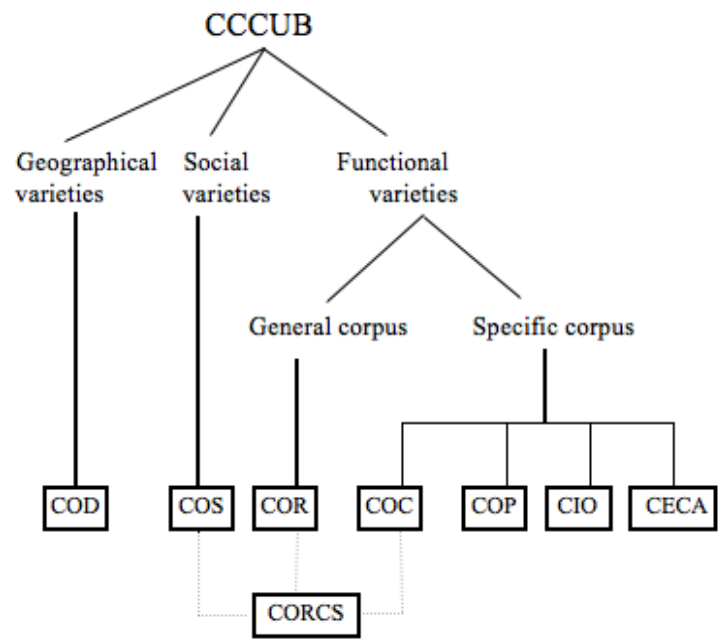

Figure I. Modules of the Corpus de Català Contemporani de la Universitat de Barcelona (CCCUB)

\section{THE CORPUS ORAL DE CONVERSA (COC)}

The basic goal of the «oral corpus of (colloquial) conversation» (COC) was to produce suitable materials for the analysis of Catalan conversation and colloquial register (spontaneous, interactive and informal spoken language). It contains io conversations, each of which lasts 30 minutes (a total of 5 hours/70,000 words). It is available as a CD-ROM, with an accompanying book (Payrató \& Alturo 2002) that contains a complete discourse transcription and partial phonetic transcription, and also on the Internet (<http://www.ub.edu/cccub/corpusoraldeconversacolloquial-coc. html>), where different files with the recording and the transcription are available. The transcription is synchronized with the voice recording. The corpus also contains ethnographic information about the communicative situation in which each conversation takes place and tables with details about the sociocultural characteristics of the interlocutors. In addition to the edited texts, 40 conversations of 30 minutes each are also available in the Department as complementary data. 


\section{I TRANSCRIPTION CONVENTIONS AND TREATMENT OF THE DATA}

The data are recorded in a discourse transcription with the addition of some aspects of intonation and other features of non-verbal vocal behaviour, according to the conventions described in this subsection (see also Du Bois et al. 1993; Payrató 1995 Payrató \& Alturo 2002; Bladas 2009). For this corpus and subsequent ones (COR and (AP), an important methodological decision regarding transcription was taken: instead of developing a new transcription system, which would contribute to an even greater fragmentation of a weak international standard, the system of Santa Barbara Corpus of Spoken American English was adopted, though very slightly modified (cf. Bladas 2009; Du Bois et al. 1993, and <https://www.linguistics.ucsb.edu/research/ santa-barbara-corpus $>$ ).

\section{I.I Prosodic aspects}

Final tone sequence

descending final tone

ascending final tone

maintaining final tone

Truncated tonal group

Maintenance of the intonation

$$
\begin{aligned}
& \text { ascending } \\
& \text { descending }
\end{aligned}
$$

Altering the voice

Intensity

$$
\begin{aligned}
& \text { high } \\
& \text { very high } \\
& \text { low } \\
& \text { very low }
\end{aligned}
$$

Time

$$
\begin{aligned}
& \text { fast } \\
& \text { slow }
\end{aligned}
$$

Short, medium and long lengthening

$$
\{(\mathrm{A}) \text { affected text }\}
$$$$
\{(\mathrm{B}) \text { affected text }\}
$$

$\{(\mathrm{EV})$ affected text $\}$

$\{(\mathrm{F})$ affected text $\}$ $\{(\mathrm{FF})$ affected text $\}$ $\{(\mathrm{P})$ affected text $\}$ $\{(\mathrm{PP})$ affected text $\}$
$\{(\mathrm{AC})$ affected text $\}$

\{(DC) affected text $\}$

: $\quad:: \quad::$ 


\section{I.2 Vocal aspects}

Simultaneous laughter with speech

Non-simultaneous laughter with speech one symbol per syllable long fragment with duration

Inhalation and exhalation

3.I.3 Pauses and overlaps

Pause

$$
\begin{aligned}
& \text { very short }(0 . \mathrm{I}<\mathrm{p}<0.3) \\
& \text { short }(\mathrm{p}<\mathrm{I}) \\
& \text { medium }(\mathrm{I} \leq \mathrm{p}<3) \\
& \text { long }(\mathrm{p}>3)
\end{aligned}
$$

Overlapping

3.I.4 Regularizations and comments

Elision

Transcriber's comment

$$
\begin{aligned}
& \text { descriptive } \\
& \text { general }
\end{aligned}
$$

3.I.5 Problematic fragments

Doubt about the transcribed text

$\{(? ?)$ affected text $\}$

Unintelligible fragment

$$
\begin{aligned}
& \text { one sign per syllable } \\
& \text { long fragment with duration }
\end{aligned}
$$

$\{(@)$ affected text $\}$

@

@R(duration)R@

$(\mathrm{INH})(\mathrm{EXH})$
(.. duration)

(... duration)

(.... duration)

[affected text]
(comment)
((comment))

(spelling of the elided sound) 


\section{I.6 Other aspects}

Second language

Truncation of word

Truncation of word and of tonal group
$\{(\mathrm{L} 2)$ affected text $\}$

$-$

$-\cdot$

\subsection{MAIN FEATURES OF THE SAMPLE AND THE SPEAKERS ${ }^{4}$}

The COC contains ten recordings of casual or colloquial conversation (interactive tenor, informal tone, spontaneous oral channel and general theme) in a friendly or family situation made in the years 1992, 1993, 1994 and 1997, as reflected in Table I.

Table I. Sample, location, and date of the recording

\begin{tabular}{|c|l|c|}
\hline Mostra & \multicolumn{1}{|c|}{ Situació } & Data \\
\hline 01 & dinner in the dining room & 1993 \\
\hline 02 & chatting on the couch after a meal out & $14 / 2 / 93$ \\
\hline 03 & lunch in the dining room & $\mathrm{DG} / 5 / 93$ \\
\hline 04 & lunch & $19 / 2 / 93$ \\
\hline 05 & chatting on the couch after a football match & nit/8/1997 \\
\hline 06 & dinner and coffee inthe dinning room & $1992-93$ \\
\hline 07 & before dinner in the dining room & $10 / 11 / 93$ \\
\hline 08 & after-dinner conversation on the sofa with the television on & 1994 \\
\hline 09 & after-dinner conversation in the dinning room & $8 / 12 / 93$ \\
\hline 10 & courtesy visit in the dining room & $8 / 12 / 93$ \\
\hline
\end{tabular}

This corpus comprises approximately 28I minutes (28 minutes on average per text or recording) and 70493 words (7049 words on average), counting on the initials of the speakers and all the symbols established in the transcription system.

4. This subsection reproduces data included in Payrató \& Alturo (2002). 
Each recording lasts between 23 and 3I minutes, and contains between 5200 and 8966 words, as can be seen in Table 2 .

Table 2. Specification of the length and the number of words of the COC

\begin{tabular}{|c|c|c|}
\hline Sample & Minutes & Words \\
\hline 01 & 30,50 & 6445 \\
\hline 02 & 28,05 & 6603 \\
\hline 03 & 29,07 & 8966 \\
\hline 04 & 23,07 & 5781 \\
\hline 05 & 23,15 & 6765 \\
\hline 06 & 29,06 & 5266 \\
\hline 07 & 30,23 & 8613 \\
\hline 08 & 31,09 & 6632 \\
\hline 09 & 30,27 & 7228 \\
\hline 10 & 27,18 & 8194 \\
\hline TOTAL & 281,67 & 70493 \\
\hline
\end{tabular}

Due to the high number of participants, the technical means used (a conventional recorder) and the surreptitious nature of the recording, the sound quality of the samples is not particularly good. Informants were adult speakers of central dialects (especially in the region of Barcelona) who, in general, do not have a specialist knowledge of Catalan.

Regarding the geographical distribution of speakers, there were 23 people from Barcelona (Barcelonès, 40.4\%) and 34 from elsewhere (59.6\%). Among those not from Barcelona, eight were from Mataró (Maresme), six from Badalona (Barcelonès), five from Esparreguera (Baix Llobregat), three from Vic (Osona), three from Caldes de Montbui (Vallès Occidental), two from Sant Martí Sescorts (Osona), I from Susqueda (La Selva), I from Vespella (Osona), I from Sant Feliu de Codines (Vallès Oriental), I from Rupià (Baix Empordà), I from Capellades (Anoia), I from Premià (Maresme) and I from Manlleu (Osona). This distribution is shown in Figure 2. 


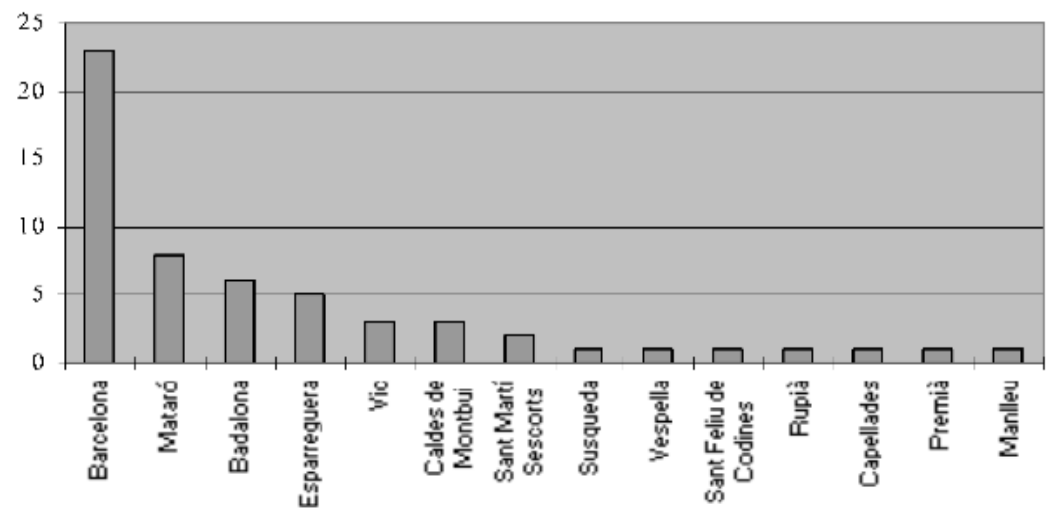

Figure 2. Geographical distribution of COC speakers by populations

By counties, 29 people were from the Barcelonès (50.9\%), nine from the Maresme ( $\mathrm{I} 5.8 \%)$, seven from Osona (I2.3\%), five from Baix Llobregat (8, 8\%), three from the Vallès Occidental (5.3\%), one from the Vallès Oriental (I.7\%), one from the Baix Empordà (I.7\%), one from La Selva (I.7\%) and one from Anoia (I.7\%). Therefore, in this part of the COC there is a clear predominance of the speakers from the Barcelonès, especially around Barcelona: the Maresme, the Baix Llobregat, the Vallès Occidental and the Vallès Oriental (47 speakers, or $82.45 \%$ of the total). The remaining ten (17.54\%) were from outside this region, specifically from Osona, Baix Empordà, La Selva and Anoia.

Regarding the sex of the speakers, 35 out of the 57 were women (61.4\%), and 22 $(38.5 \%)$ were men. Regarding the social stratification of speakers, two major groups are established: ${ }^{5}$

a) 30 middle-class speakers (52.63\%), 28 of whom were employees or middle range technical staff (49.12\%), and two senior or professional technical staff (3.5\%).

b) 25 working class speakers $(43.85 \%)$, I8 of whom were manual workers (3I.57\%), six old manual workers (I0.52\%), and one a supervisor (I.75\%).

No social group was stipulated in the case of two children (3.5\%) due to lack of data and because their linguistic or communicative participation in the conversations was minimal. The date are presented in chart form in Figure 3.

5. This information is based on the proposal of the Survey of the Metropolitan Region of Barcelona (Subirats et al. 1992). For more detailed information about the geographical and social characteristics of the speakers, see Annex 2 of Payrató \& Alturo (2002: 2O-2I). 


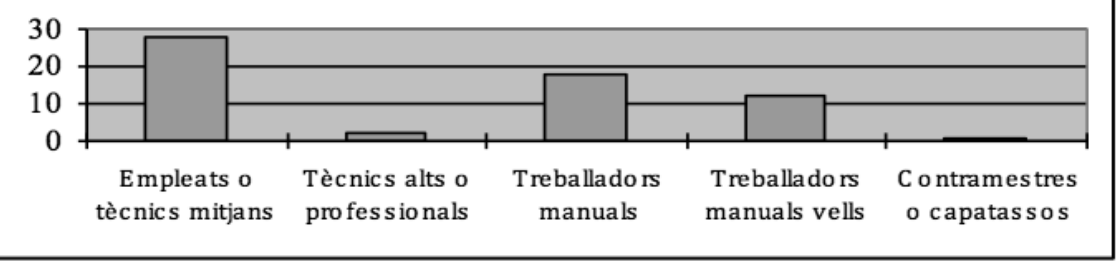

Figure 3. Social distribution of the speakers of the COC

\section{$3 \cdot 3$ SAMPLE}

The on-screen presentation of the CD is shown in Image I, which reproduces the beginning of conversation $\mathrm{I}$.

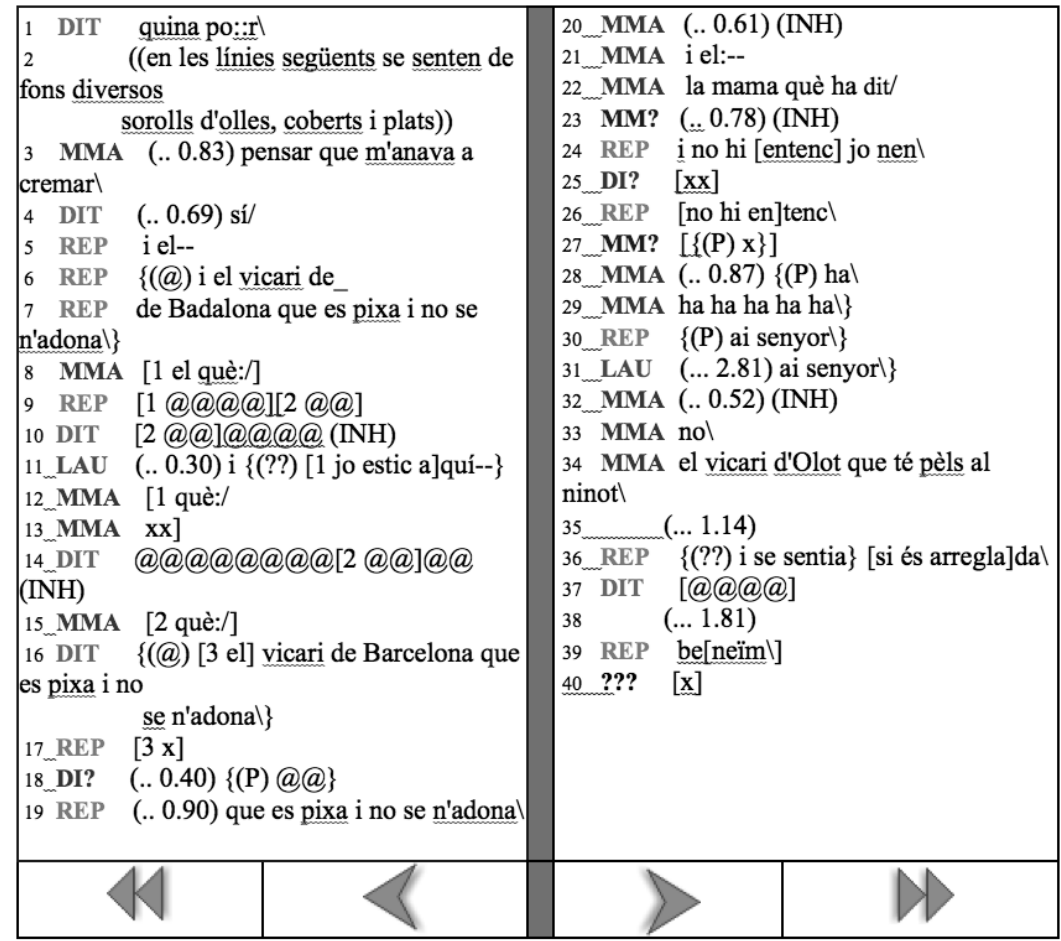

Image I. Reproduction of the screen access to the COC corpus (conversation I) 
From this screen, the soundtrack (synchronized with the text), the phonetic transcription of the text, the ethnographic information on the communicative situation and the basic characteristics of speakers (age, origin, profession, social group) can be accessed by clicking on buttons and boxes (not shown in the image). In the printed book (Payrató \& Alturo 2002), the text is shown in parallel columns (with discursive and phonetic transcription) of the first five minutes of each conversation (see table 3 ).

Table 3. Presentation of the corpus (example of a fragment of conversation 7)

CONVERSA 07

Transcripció discursiva

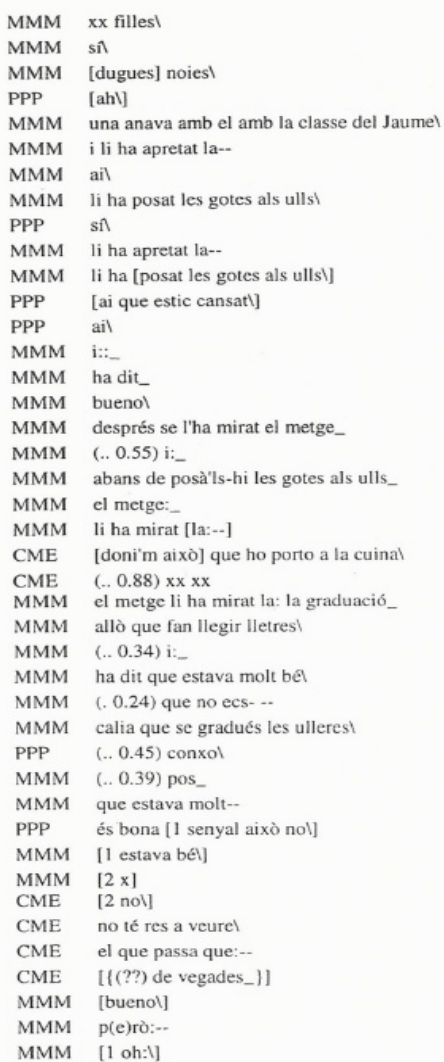

Transcripció fonètica 


\section{THE CORPUS ORAL DE REGISTRES (COR)}

The basic goal of the «oral corpus of registers» (COR) was to produce suitable materials for the comparative analysis of Catalan registers and typical speech events in the studied community. It includes 26 speech events and I 68 texts of different length (a total of 9 hours/154,000 words, approximately) and is also available as a CD-ROM, with an accompanying book (Alturo et al. 2004) containing complete discourse transcriptions, and also on the Internet (<http://www.ub.edu/cccub/corpusoralderegistrescor.html>). As above, the transcribed text in the CD-ROM and the voice recording are synchronized. The corpus is structured into nine areas of use or domains (judicial and civil, business, education, politics, culture, religion, media, private communication and provoked interactions) and 26 genres (presentation, sermon, story, recipe, etc.). Ethnographic information about the communicative situation in which each speech event takes place is included, as well as tables containing details about the sociocultural characteristics of the interlocutors. The transcription applies the same conventions as in the COC (see 3.I), but this time without phonetic transcription.

\section{I ITEMS AND STRUCTURE}

The COR is structured in fields and in discourse genres. ${ }^{6}$ By domain we understand the sociocultural context in which a particular discourse is produced, such as education, business, and so on. The term discourse or speech genre refers to the communicative event occurring in a particular social context, for example a press conference or the message left on an answering machine.

The publication comprises a total of I68 texts that make up a sample of 26 speech genres in seven different fields (see table 4). This sample aims to offer a diverse, heterogeneous body of reference material for the study of functional variation in contemporary oral Catalan. The CD-ROM contains the full texts, which can be consulted directly or through any word processing program. The printed edition includes only brief fragments of each genre. The set of materials and the structure of the corpus are reproduced in Table 4 .

6. This subsection reproduces data included in Alturo et al. (2004: 5). 
Table 4. Items and structure of the COR

\begin{tabular}{|c|c|c|c|c|c|}
\hline CODE & DOMAIN & DISCOURSE GENRE & TEXTS & WORDS & MINUTES \\
\hline CIVI & \multirow{2}{*}{ CIVIL } & Courtroom trial & I & 950 & 4,52 \\
\hline $\mathrm{CIV}_{2}$ & & Civil wedding & I & 3097 & $2 \mathrm{I}, 5 \mathrm{I}$ \\
\hline EDUCI & \multirow{4}{*}{$\begin{array}{c}\text { EDUCATIO- } \\
\text { NAL- } \\
\text { ACADEMIC- } \\
\text { SCIENTIFIC } \\
\end{array}$} & Teachers meeting & I & 9579 & 33,45 \\
\hline $\mathrm{EDUC}_{2}$ & & School story & I & $22 \mathrm{II}$ & 7,55 \\
\hline $\mathrm{EDUC}_{3}$ & & Master class & $\mathrm{I}$ & 7978 & 30,25 \\
\hline $\mathrm{EDUC}_{4}$ & & Conference & $\mathrm{I}$ & 1393 & 25,50 \\
\hline POLI & \multirow{4}{*}{ POLITIC } & Political meeting & $\mathrm{I}$ & 6268 & 30 \\
\hline POL2 & & Parliamentary session & I & 6587 & 32 \\
\hline $\mathrm{POL}_{3}$ & & $\begin{array}{c}\text { Plenary session of a town } \\
\text { hall }\end{array}$ & I & 4413 & 40,38 \\
\hline $\mathrm{POL}_{4}$ & & Press conference & $\mathrm{I}$ & 13643 & $5 \mathrm{I}$ \\
\hline PRIVI & \multirow{3}{*}{ PRIVATE } & Familiar story & $\mathrm{I}$ & II4O & 4,22 \\
\hline $\mathrm{PRIV}_{2}$ & & $\begin{array}{c}\text { Messages on an answering } \\
\text { machine }\end{array}$ & 100 & 7066 & 40,45 \\
\hline $\mathrm{PRIV}_{3}$ & & Telephone conversation & $\mathrm{I}$ & IIO8I & 35,50 \\
\hline EMPI & \multirow{6}{*}{$\begin{array}{l}\text { BUSINESS- } \\
\text { COMMER- } \\
\text { CIAL }\end{array}$} & Interview of practices & $\mathrm{I}$ & 4560 & 22 \\
\hline $\mathrm{EMP}_{2}$ & & Technical talk & $\mathrm{I}$ & 4968 & 30,15 \\
\hline $\mathrm{EMP}_{3}$ & & Fish selling & $\mathrm{I}$ & 7202 & 33,30 \\
\hline $\mathrm{EMP}_{4}$ & & Hiring a trip & $\mathrm{I}$ & 4940 & 17,35 \\
\hline $\mathrm{EMP}_{5}$ & & Market sale & 25 & 7267 & 26,56 \\
\hline EMP6 & & Telephone inquiries & 20 & 8972 & 30,20 \\
\hline CULTI & \multirow{5}{*}{ CULTURAL } & Presentation of a video & $\mathrm{I}$ & 4278 & 27,40 \\
\hline $\mathrm{CULT}_{2}$ & & Guided tour & $\mathrm{I}$ & 8943 & 30 \\
\hline $\mathrm{CULT}_{3}$ & & Theater company rehearsal & $\mathrm{I}$ & $935 \mathrm{I}$ & 30 \\
\hline $\mathrm{CULT}_{4}$ & & Poetry recital & $\mathrm{I}$ & 4723 & 46 \\
\hline RELI & & Sunday sermon & $\mathrm{I}$ & 2485 & $\mathrm{II}, \mathrm{IS}$ \\
\hline REL2 & \multirow[t]{2}{*}{ RELIGIOUS } & Wedding & $\mathrm{I}$ & 7 OII & 34 \\
\hline $\mathrm{REL}_{3}$ & & Mass & $\mathrm{I}$ & 4092 & 27 \\
\hline & & & $\begin{array}{l}\text { TOTAL } \\
=168\end{array}$ & $\begin{array}{r}\text { TOTAL } \\
=154198\end{array}$ & $\begin{array}{l}\text { TOTAL } \\
=721,44\end{array}$ \\
\hline
\end{tabular}




\subsection{SAMPLES}

We now provide three samples corresponding to three areas: political (and public), cultural and private. The first is the beginning of a plenary session of a city council, the second a play rehearsal by a non-professional theatre group, and the third the telling of a story in a school setting.

For the purposes of contextualization, data regarding each extract are provided, including information about the interlocutors (the personal or professional relationship between them, the role they play in the interaction, age, social class, etc.), the setting, and any other relevant features in each communicative exchange.

\subsection{Plenary session of a town hall}

Plenary session of the Town Hall of Arenys de Munt held on March 4, 1997. The session is held in a meeting room of the town hall, where there is a round table and shelves with books. There are seven participants, six of home are men between 30 and 50 years old (SOS, mayor and president of the plenary; CAA, town councilor; REE, councilor for culture; SOO, councilor for government; DRR, municipal group spokesman, and HHG, councilor), and one is a 28 -year-old woman (NTT, secretary of the plenary session). The event is open to the public and broadcast live on local radio.

The plenary president opens the session and puts the minutes of the previous session to a vote. All the councilors have previously received the minutes in writing. Next, the president presents the points of the agenda that must be dealt with; then, after questions (submitted previously in writing to the mayor), he puts the proposals to a vote.

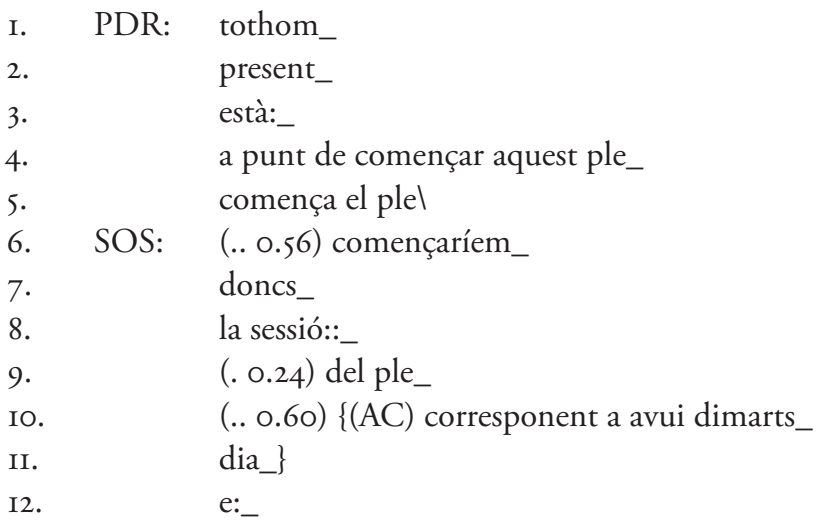




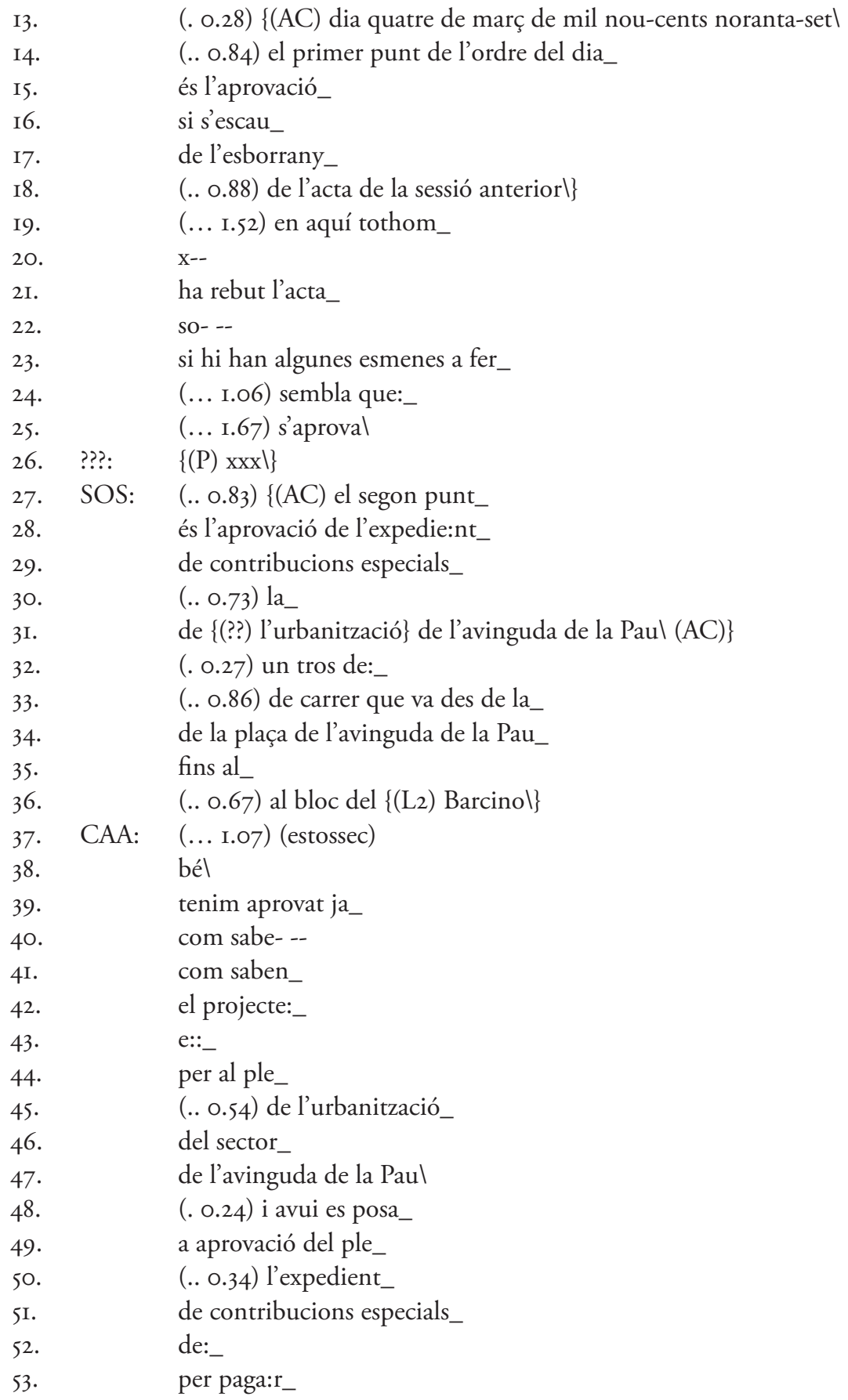




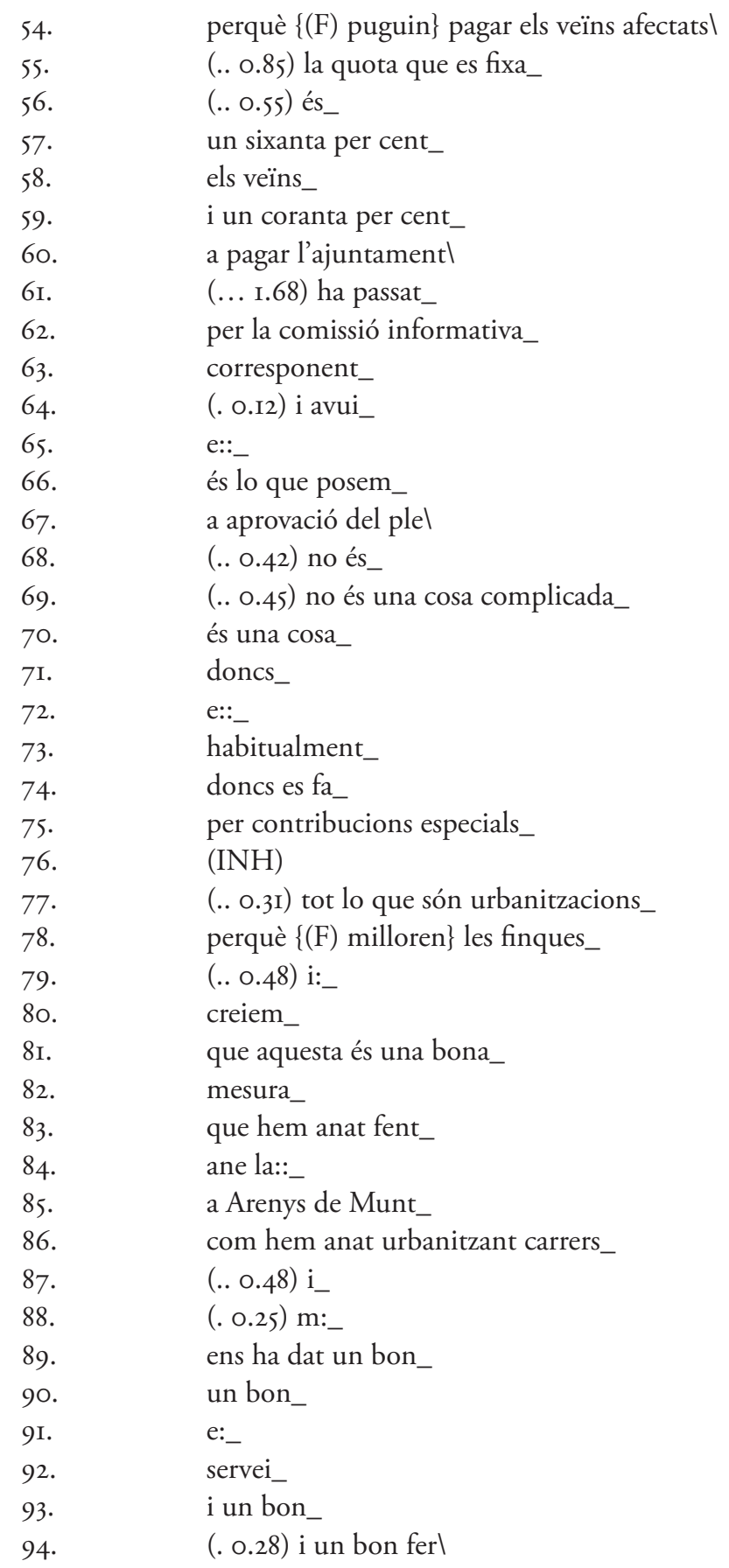




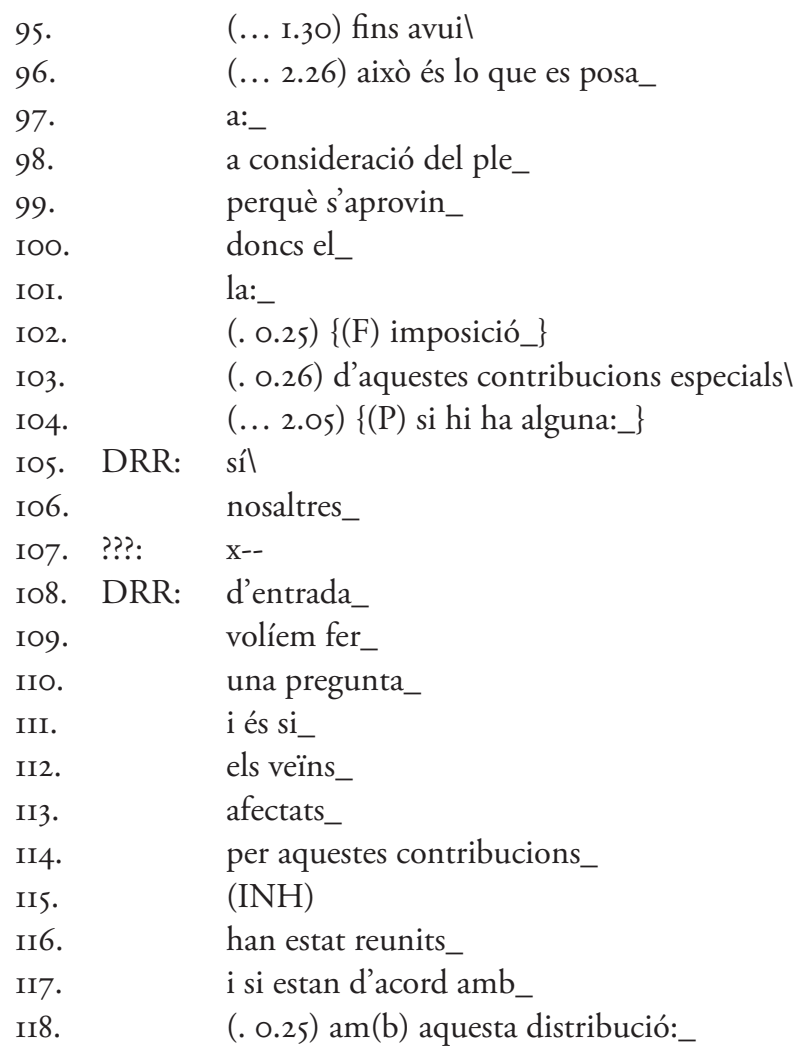

\subsubsection{Political meeting}

Meeting of Esquerra Republicana de Catalunya at the Palau de Congressos in Barcelona on February 29, 1996, in the electoral campaign before the elections of March 3 of the same year. Eleven speakers (candidates, members of the executive council and a guest from Eusko Alkartasuna), as well as the director of the event, take part. Thirty minutes of the meeting are transcribed, corresponding to interventions by Albert Roig (ARR, Vilanova i la Geltrú, 3I years old, Catalan-speaking family, primary school teacher and regional president of ERC del Penedès-Anoia), Begoña Lasagabaster Olazábal (BLL, Irun, 34 years old, Basque-speaking family, a graduated in European studies at the College of Europe, Legal Department, Bruges, Belgium, Congressman by Eusko Alkartasuna), and Pilar Rahola Martínez (PPR, Barcelona, 38, Catalan-speaking family, graduated in Hispanic and Catalan philology, fourth Deputy Mayor of the City Council of Barcelona, responsible for commerce, delegated to the 
Congress for Esquerra Republicana de Catalunya). The presentations made were also transcribed. The director of the event is Josep Huguet Biosca (JHH, Manresa, 45 years old, Catalan-speaking family, degrees in engineering and a history degree, member of parliament).

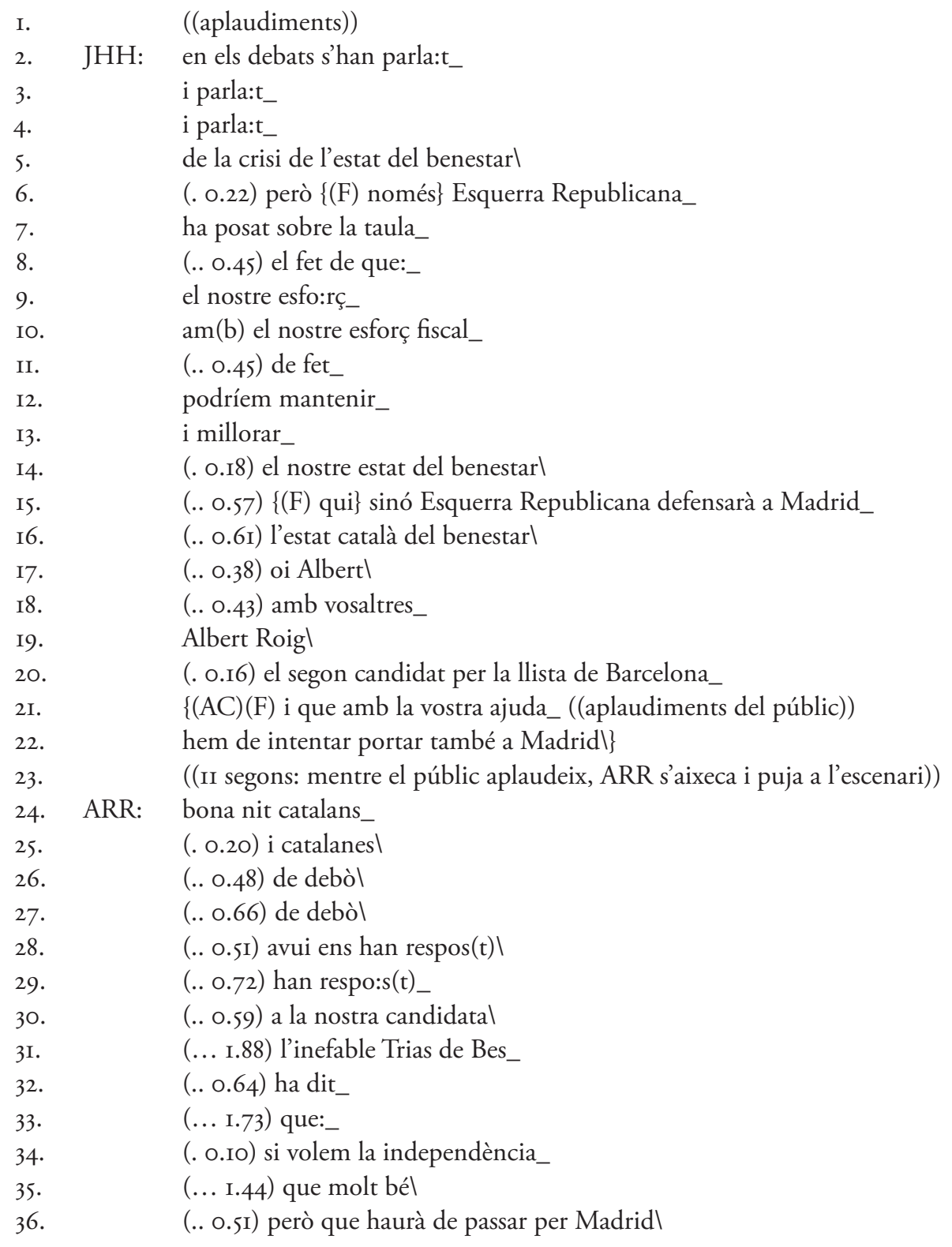




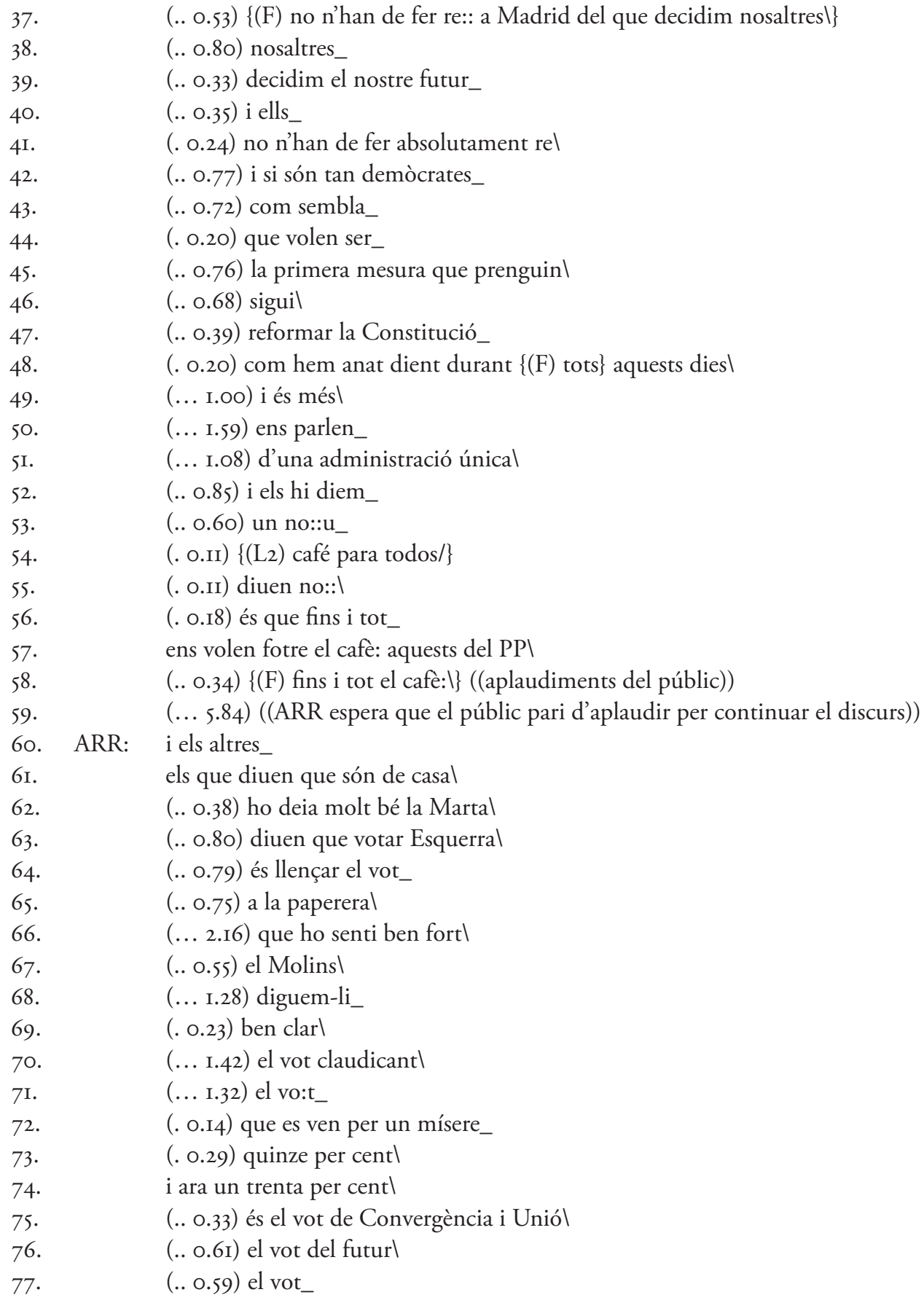




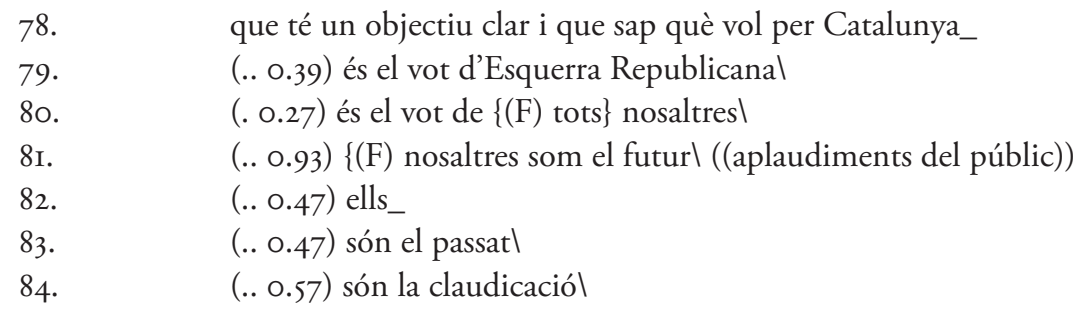

\subsubsection{School story}

Telling of the story "The puppets» inside the daily activities of a kindergarten class (3 years). The recording took place on one day in the academic year 1994-1995, in a classroom in a municipal nursery school in Barcelona. The teacher who tells the story (MOL) has a book with illustrations, which she shows to the children listening to her. Some children (NEN) interrupt the teacher to participate in the story-telling, especially one of them, who intervenes more often than the others. The teacher is a middle-class woman, 55 years old, from a Catalan-speaking Catalan family, but without any specific studies of Catalan.

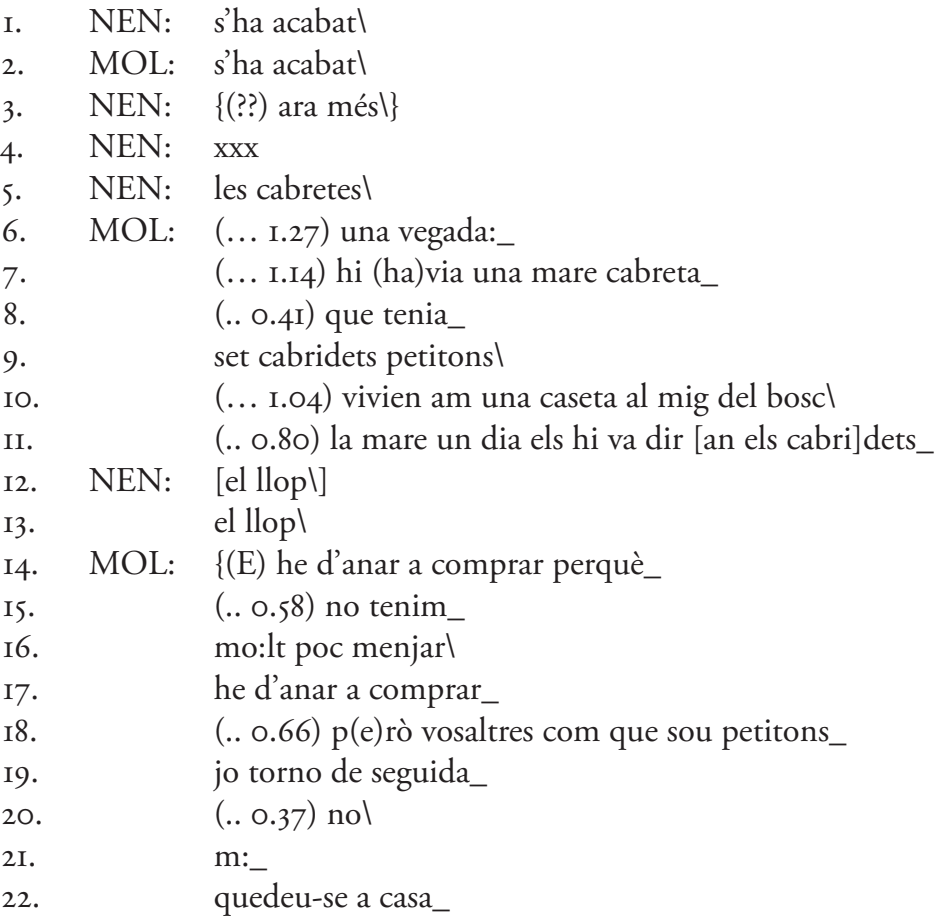




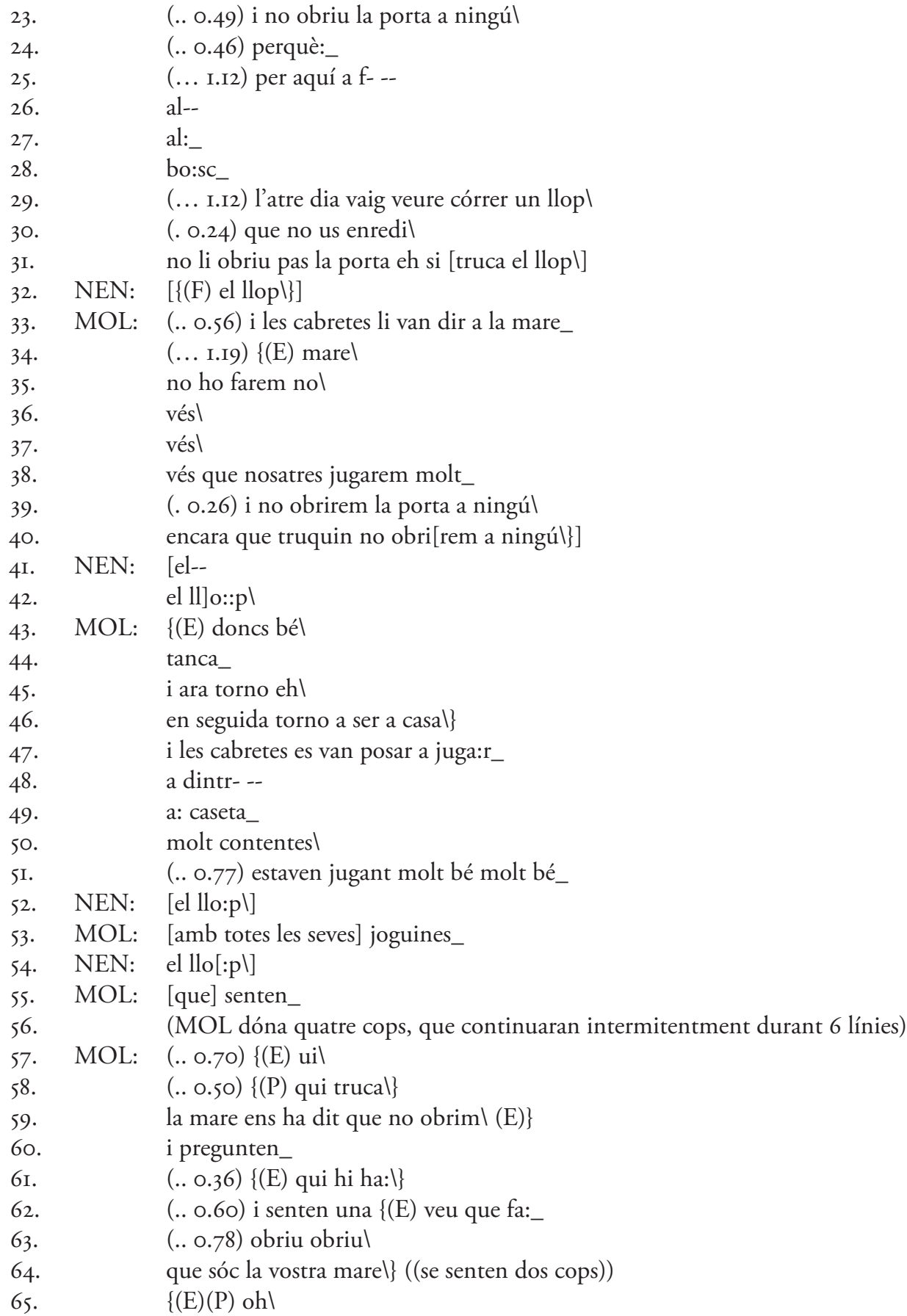




\begin{tabular}{|c|c|}
\hline 66. & $(. .0 .85)$ ai nol \\
\hline 67. & la mare no pot serl \\
\hline 68. & (.. 0.5I) que la mare no té aquesta veul\} \\
\hline 69. & (... I.64) deu ser el llop $\backslash$ \\
\hline 70. & que ens ho va dir la marel \\
\hline 7I. & no obrirem ehl \\
\hline 72 . & no obrirem $\backslash$ \\
\hline 73. & que la mare ens va dir que no obríssiml\} \\
\hline 74. & (.. o.88) i les cabretes li diuen_ \\
\hline 75 . & $(. .0 .63)\{(\mathrm{E})$ tu no ets la nostra marel \\
\hline 76. & tu ets el llop $\backslash$ \\
\hline 77 . & i no t'obrirem la portal \\
\hline 78. & vés-te’n\ \\
\hline 79 . & vés-te’n $\mid\}$ \\
\hline 80. & $(.$. o.48) i el llop_((se senten dos cops $))$ \\
\hline 8I. & $\{(\mathrm{E}) \mathrm{a}: \mathrm{h} \backslash$ \\
\hline 82. & (.. 0.69) m'heu descobert $\backslash$ \\
\hline 83. & doncs ja tornarél \\
\hline 84 . & ja tornarél\} \\
\hline 85 . & (.. 0.36) i se'n va anar tot enfadat \\
\hline
\end{tabular}

\section{THE CORPUS AUDIOVISUAL PLURILINGÜE (CAP)}

The "plurilingual audiovisual corpus» (CAP) contains audiovisual recordings and the accompanying transcriptions of I2 participants. The corpus is multilingual, with samples in Catalan, Spanish and English; multitextual, since it includes five types of text (narration, description, argumentation, exposition and instruction) and two procedures for eliciting the information (experiential and experimental); and multimodal (it contains texts, voice recordings and images). The corpus was begun as part of the project VARCOM and was developed later under the project PRAGMAESTIL (see section I.I).

This corpus was compiled by the research group GrEPAD (Grup d'Estudis de Pragmàtica i Anàlisi del Discurs, (see <http://www.ub.edu/grepad>), which is integrated into the GEV (Grup d'Estudi de la Variació, see <http://www.ub.edu/GEV>), the main research group in the Section of Catalan Language of the University of Barcelona. As can be seen in Figure 2 (see section 2), this corpus completes the series of applied materials made of the corpora COC (colloquial conversation, Payrató \& Alturo 2002), COR (registers, Alturo et al. 2004), and COS (social varieties, Boix et al. 2006), all of which are part of the CCCUB. 
Lluís Payrató \& Neus Nogué

The oral corpora in Catalan and research into casual Catalan:

the corpora of conversation and functional varieties of the CCCUB

5. I CONSTITUTION OF THE CORPUS. RESEARCH PROTOCOL, METHODOLOGY AND ACCESS

\section{I.I Informants}

The informants were 18 women aged between 18 and 30 years who were educated in the 1980 and 1990 s (with a posterior selection of I2 final informants). All of them are second-cycle students of Economics or similar subjects who were born and currently reside in the metropolitan region of Barcelona and, by extension, in the Central Catalan linguistic area, with a level of English of Cambridge First Certificate (FCE) or equivalent. According to their family tongue, they belong to one of the following groups: Catalan-speaking (with Catalan as LI), Spanish-speaking (with Spanish as $\mathrm{LI}$ ) or raised in a bilingual home (with both Catalan and Spanish as family tongues).

\section{I.2 Sessions, recordings and transcriptions}

Three recording sessions took place (LI/L2/English), with a minimum of 30 days between each session and the next. Digital recording was performed using two cameras (general view/facial view). We then selected $\mathrm{I} 2$ of the $\mathrm{I} 8$ recordings, depending on factors such as fluency in the three languages, competence in English, and lack of non-verbal inhibition. The transcription follows the same conventions as COC (see 3.I), but without phonetic transcription.

\section{I.3 Elicitation system}

The elicitation system consisted of three semidirected interviews in which informants were requested to produce texts, following the guidelines shown in Table 5.

In all sessions, five experimental texts and five experiential texts were produced, which form the CAP. The order of elicitation of texts was the same in the three sessions.

The first session, in the informant's LI, included information about her linguistic background (following the format of the "European Language Portfolio»). The second session was developed in the informant's L2, and the third in English, with a part devoted to the linguistic ideologies of the informant. Each session also included a sequence of free conversation. 
Table 5. Session guidelines

\begin{tabular}{|c|c|c|c|c|c|c|}
\hline \multirow{13}{*}{$1^{\text {st }}$ day } & \multirow{13}{*}{ L1 } & \multirow{13}{*}{ 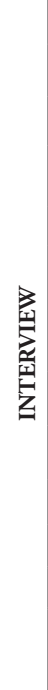 } & \multicolumn{4}{|c|}{ GENERAL DETAILS (LINGUISTIC BIOGRAPHY) } \\
\hline & & & \multirow{5}{*}{\multicolumn{2}{|c|}{ 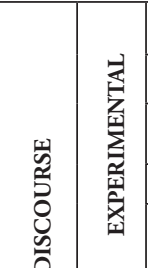 }} & Narrative & Frog, where are you? \\
\hline & & & & & Instructive & Map of an imaginary village \\
\hline & & & & & Argumentative & In favour: living in the country / city \\
\hline & & & & & Descriptive & House from the sIms computer game \\
\hline & & & & & Expository & Immigration: the current situation \\
\hline & & & \multirow{5}{*}{ 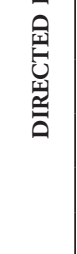 } & \multirow{5}{*}{ 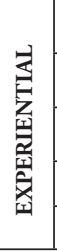 } & Argumentative & Recommend a film or book \\
\hline & & & & & Instructive & From class to your home \\
\hline & & & & & Descriptive & What your home is like \\
\hline & & & & & Expository & What you do at the weekends \\
\hline & & & & & Narrative & A dangerous or frightening situation \\
\hline & & & \multicolumn{4}{|c|}{ CONVERSATION } \\
\hline & & & \multicolumn{3}{|c|}{\begin{tabular}{|l|}
$\begin{array}{l}\text { EUROPEAN LANGUAGE } \\
\text { PORTFOLIO }\end{array}$ \\
\end{tabular}} & Language passport \\
\hline \multirow{11}{*}{ 2n day } & \multirow{11}{*}{ L2 } & \multirow{11}{*}{ 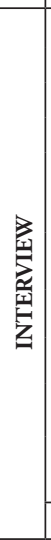 } & \multirow{10}{*}{ 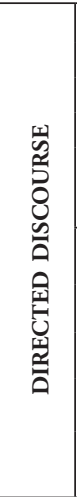 } & \multirow{5}{*}{ 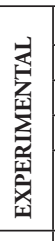 } & Narrative & Frog, where are you? \\
\hline & & & & & Instructive & Map of an imaginary village \\
\hline & & & & & Argumentative & In favour: living in the country / city \\
\hline & & & & & Descriptive & House from the sIMs computer game \\
\hline & & & & & Expository & Immigration: the current situation \\
\hline & & & & \multirow{5}{*}{ 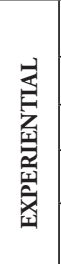 } & Argumentative & Recommend a film or book \\
\hline & & & & & Instructive & From class to your home \\
\hline & & & & & Descriptive & What your home is like \\
\hline & & & & & Expository & What you do at the weekends \\
\hline & & & & & Narrative & A dangerous or frightening situation \\
\hline & & & \multicolumn{4}{|c|}{$\begin{array}{l}1 \\
\text { CONVERSATION } \\
\end{array}$} \\
\hline \multirow{11}{*}{ 3r day } & \multirow{11}{*}{ L3 } & \multirow{11}{*}{ 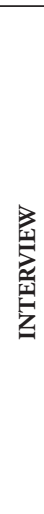 } & \multirow{10}{*}{ 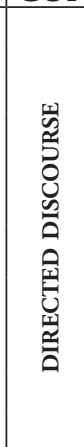 } & \multirow{5}{*}{ 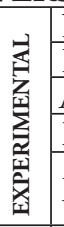 } & Narrative & Frog, where are you? \\
\hline & & & & & \begin{tabular}{|l|l} 
Instructive \\
\end{tabular} & Map of an imaginary village \\
\hline & & & & & Argumentative & In favour: living in the country / city \\
\hline & & & & & Descriptive & House from the sIMs computer game \\
\hline & & & & & Expository & Immigration: the current situation \\
\hline & & & & \multirow{5}{*}{ 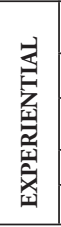 } & Argumentative & Recommend a film or book \\
\hline & & & & & Instructive & From class to your home \\
\hline & & & & & Descriptive & What your home is like \\
\hline & & & & & Expository & What you do at the weekends \\
\hline & & & & & Narrative & A dangerous or frightening situation \\
\hline & & & \multicolumn{4}{|c|}{ CONVERSATION } \\
\hline
\end{tabular}


In the case of texts based on the experience of the speakers (experiential texts), the response was stimulated by a simple verbal request and no materials were used:

(a) Argumentative: recommending a film or book.

(b) Instructive: explaining how the informant goes from class to her home.

(c) Descriptive: describing the room and the apartment/house where the informant lives.

(d) Expository: the current situation of immigration in Europe.

(e) Narrative: narrating a dangerous or frightening situation.

In the case of eliciting experimental texts, responses were stimulated using visual materials (drawings and pictures), which guided the informants towards typical situations corresponding to:

(a) Narrative: a story about a frog that escapes and a boy who tries to find it. ${ }^{7}$

(b) Descriptive: the description of an apartment.

(c) Argumentative: preference for life in the country or life in the city.

(d) Expository: the current situation of immigration in Europe.

(e) Instructive: how to follow a route along the streets on a map of an imaginary village.

5.I.4 Formats and access. Examples

The CAP is conceived as a «monitor» corpus that can be expanded and which initially contains 360 core samples and 48 extra samples. In total the corpus contains approximately 18 hours of recordings (24 hours of interviews) and approximately IOO,000 words in transcription. It is stored as a DVD (Payrató \& Fitó 2008) and general tagging is not envisaged, being restricted to the adapted subcorpora.

The combination of text, sound and image means that the corpus contains text files (discourse transcription) with corresponding audiovisual recordings (image with sound). The following fragment is an example of the experimental narrative text (narration of a story prompted by images shown to the participant shortly before): Dial Press.

7. This well known story is based on the book by Mercer Meyer (1969): Frog, where are you? New York: 


\section{File CITN2ICS (fragment)}

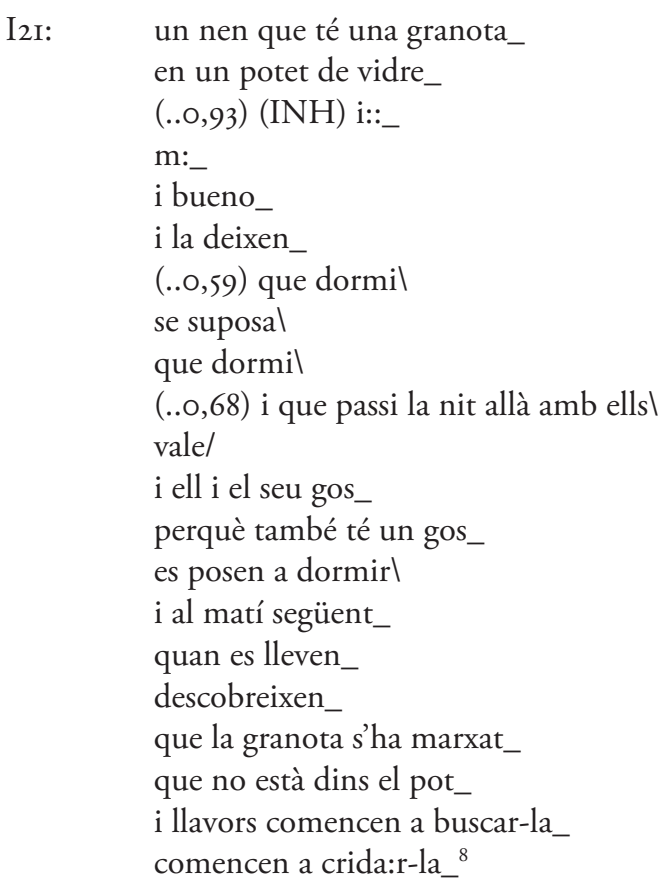

\section{I.5 Corpus structure}

The corpus structure is shown in the tables below, where samples are classified according to a combination of features relating to text type, genre, language (Catalan, Spanish, English), and elicitation procedures.

8. Literal translation: «A boy who has a frog in a small glass jar, and and well. and they let it sleep, it's supposed, sleep, and it spends the night there with them, OK?, and he and his dog, because he also has a dog, they go to sleep. And next morning, when they get up, they see that the frog isn't there, that it's not in the jar, and then they begin to look for it, they begin to call it.» 
Table 6. Corpus structure according to language and text type

\begin{tabular}{|c|c|c|c|c|c|c|c|c|c|}
\hline & & & & & Narrative & & & & \\
\hline & & & L1 & & Descriptive & & & & \\
\hline & & & & experimental & Expository & & & & \\
\hline & & & & & Instructive & & & & \\
\hline & & Catalan & or & & Argumentative & 10 & & & \\
\hline & & & & & \begin{tabular}{|l} 
Narrative \\
\end{tabular} & & & & \\
\hline & & & & & Descriptive & & & & \\
\hline & & & I2 & experiential & Expository & & & & \\
\hline & & & $\mathrm{L} 2$ & & Instructive & & & & \\
\hline & & & & & Argumentative & & & & \\
\hline & & & & & Narrative & & & & \\
\hline & & & $\mathrm{L} 2$ & & Descriptive & & & & \\
\hline & & & & experimental & Expository & & & 30 samples & \\
\hline & & & & & Instructive & & 30 comples & & \\
\hline 党 & 它 & Spanish & or & & Argumentative & 10 & J0 sampies & $\mathrm{x}$ & $=360$ \\
\hline & & & & & Narrative & & / informant & 12 & samples \\
\hline & & & & & Descriptive & & & informants & \\
\hline & & & I1 & experiential & Expository & & & & \\
\hline & & & L1 & & Instructive & & & & \\
\hline & & & & & Argumentative & & & & \\
\hline & & & & & Narrative & & & & \\
\hline & & & & & Descriptive & & & & \\
\hline & & & & experimental & Expository & & & & \\
\hline & & & & & Instructive & & & & \\
\hline & & English & $\mathrm{L} 3$ & & Argumentative & 10 & & & \\
\hline & & & & & Narrative & 10 & & & \\
\hline & & & & & Descriptive & & & & \\
\hline & & & & experiential & Expository & & & & \\
\hline & & & & & Instructive & & & & \\
\hline & & & & & Argumentative & & & & \\
\hline
\end{tabular}


Table 7. Corpus structure according to language and genre (conversation)

\begin{tabular}{|c|c|c|c|c|c|c|c|}
\hline \multirow{5}{*}{$\begin{array}{l}0 \\
0 \\
\tilde{0} \\
\tilde{0}\end{array}$} & \multirow{5}{*}{ 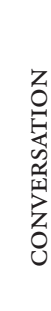 } & & $\mathrm{L} 1$ & 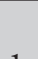 & \multirow{5}{*}{$\begin{array}{l}3 \text { samples } \\
\text { / informant }\end{array}$} & \multirow{4}{*}{$\begin{array}{c}3 \text { samples } \\
x \\
12 \text { informants }\end{array}$} & \multirow{4}{*}{$=36$ samples } \\
\hline & & & L2 & & & & \\
\hline & & \multirow{2}{*}{ Spanish } & L1 & & & & \\
\hline & & & L2 & & & & \\
\hline & & English & L3 & 1 & & & \\
\hline
\end{tabular}

Table 8. Corpus structure according to genre

\begin{tabular}{|c|c|c|c|c|}
\hline \multirow{3}{*}{$\begin{array}{l}\text { D } \\
0 \\
0 \\
0\end{array}$} & TEXTUAL & \multirow{3}{*}{$\begin{array}{c}3+ \\
1 \text { sample / informant }\end{array}$} & \multirow{4}{*}{$\begin{array}{c}34 \text { samples } \\
x \\
12 \text { informants }\end{array}$} & \multirow[b]{3}{*}{$=408$ samples } \\
\hline & CONVERSATION & & & \\
\hline & LANGUAGE IDEOLOGIES & & & \\
\hline & TOTAL & $=34$ samples $/$ informant & & \\
\hline
\end{tabular}

\section{I.6 Codification}

The samples are coded according to four criteria: relation to the speaker, elicitation procedure, text type and informant number. The resulting code is shown as follows:

(I) Example of codification: $\mathrm{C}$ I $\mathrm{T}$ N or CC

(2) Relation to the speaker: I (first language) / 2 (second language) / 3 (third language)

(3) Elicitation strategy: T (experimental) / C (experiential) / E (interview)

(4) Type of text: N (narrative) / D (descriptive) / E (expository) / I (instructive) / A (argumentative) / C (conversation) / R (representations).

(5) Informant number: OI, 04, 05, 06 (LI = Catalan) / 06, I2, I4, I5 (L2 = Spanish) / 2I, 22, 24, 25 ( $\mathrm{LI}=$ Catalan/Spanish)

(6) Family language: CC (Catalan) / SS (Spanish) / CS (Catalan/Spanish) / EE (English) / DD (German). 


\subsection{SAMPLES}

In the following sections we provide a sample corresponding to each of the five main text types (all of them obtained as experiential texts regarding the elicitation strategy).

\subsection{Narrative}

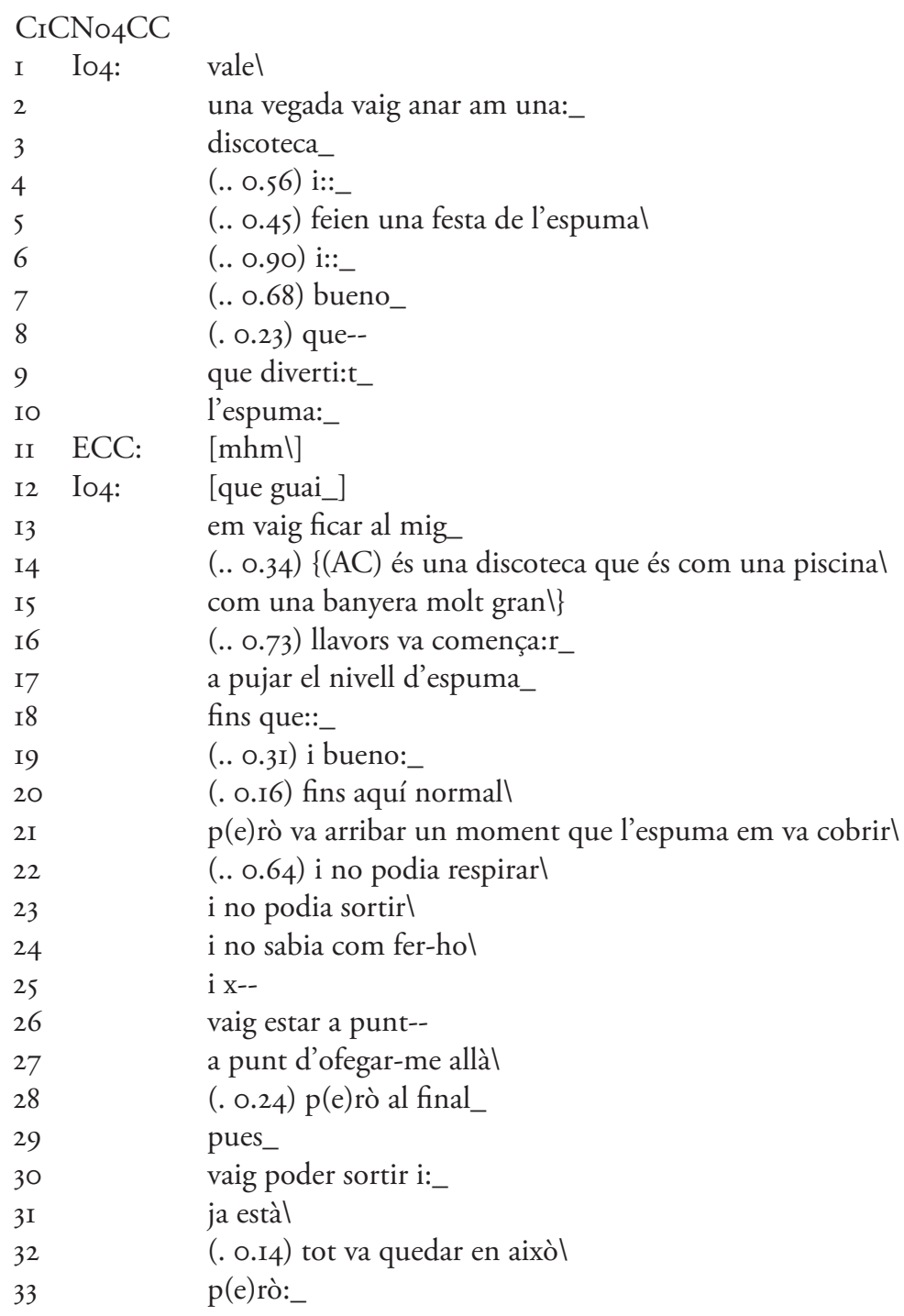




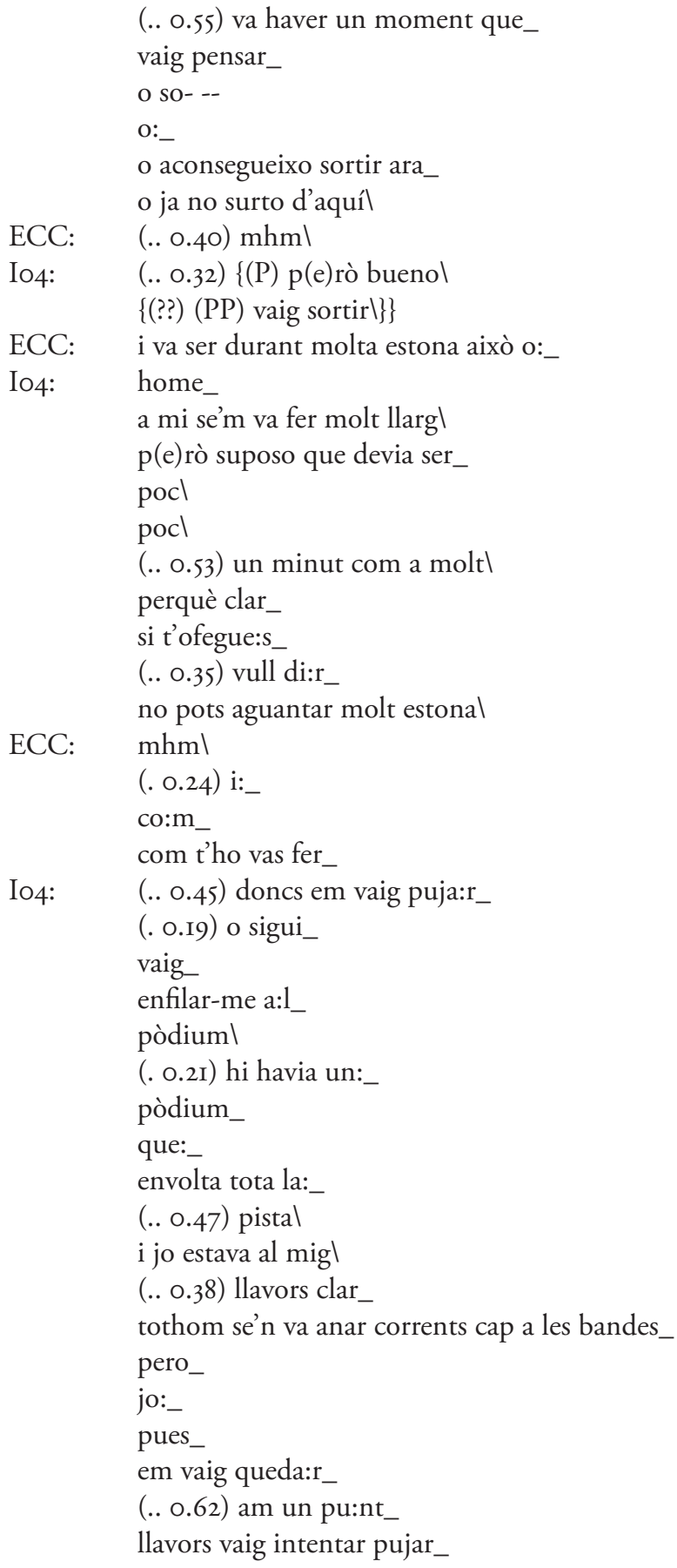




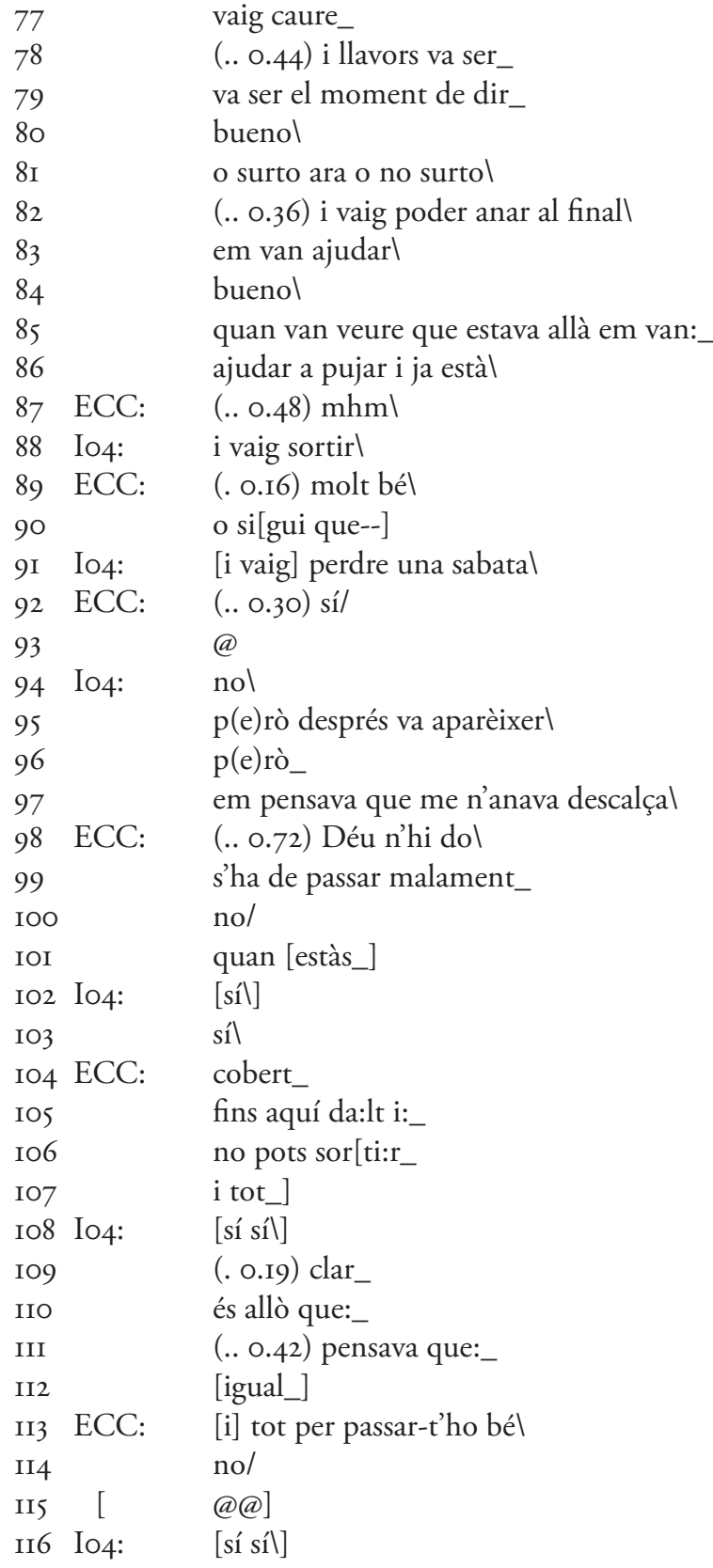




\subsubsection{Descriptive}

\begin{tabular}{|c|c|c|}
\hline \multicolumn{2}{|c|}{$\mathrm{C}_{1} \mathrm{CD}_{22} \mathrm{CS}$} & \\
\hline I & I22: & e:1 lloc/ \\
\hline 2 & & $\{(? ?)$ valel $\}$ \\
\hline 3 & ECC: & síl \\
\hline 4 & I22: & (INH) \\
\hline 5 & & $e::_{-}$ \\
\hline 6 & & doncs bél \\
\hline 7 & & $(. .0 .80) \mathrm{m}::_{-}$ \\
\hline 8 & & (.. o.32) le:s_ \\
\hline 9 & & cases són:_- \\
\hline IO & & (.. 0.49) a ve(u)rel \\
\hline II & & hi ha_ \\
\hline 12 & & hi ha de tots estils $\backslash$ \\
\hline $\mathrm{I} 3$ & & vale/ \\
\hline I4 & & hi ha una mica d'antigues_. \\
\hline I5 & & i així_ \\
\hline I6 & & perquè:_ \\
\hline I7 & & $\left\{(\mathrm{AC}) \mathrm{la} \mathbf{}_{-}\right.$ \\
\hline I8 & & zona no està malament $\mid\}$ \\
\hline 19 & & @@ \\
\hline 20 & & [(INH)] \\
\hline 2I & ECC: & {$[\mathrm{mhml}]$} \\
\hline 22 & I22: & $\mathrm{i}::_{-}$ \\
\hline 23 & & hi ha_ \\
\hline 24 & & edificis_ \\
\hline 25 & & no gaire alts। \\
\hline 26 & & tampocl \\
\hline 27 & & de set o vuit pisos_ \\
\hline 28 & & (INH) \\
\hline 29 & & $\mathrm{i}::_{-}$ \\
\hline 30 & & le:s_ \\
\hline 3I & & avingudes estan ben cuidades_ \\
\hline 32 & & (INH) \\
\hline 33 & & {$[\{(? ?)$ hi han moltes-- $\}]$} \\
\hline 34 & ECC: & [i el pis en concret_] \\
\hline 35 & & una mica la_ \\
\hline 36 & I22: & {$[\{(\mathrm{F}) \mathrm{a}: \mathrm{h} \backslash$} \\
\hline 37 & & el pis $\mid\}]$ \\
\hline 38 & ECC: & [la distribu]ció_ \\
\hline 39 & & $\{(? ?)$ sí \\
\hline 40 & & co:m_\} \\
\hline
\end{tabular}




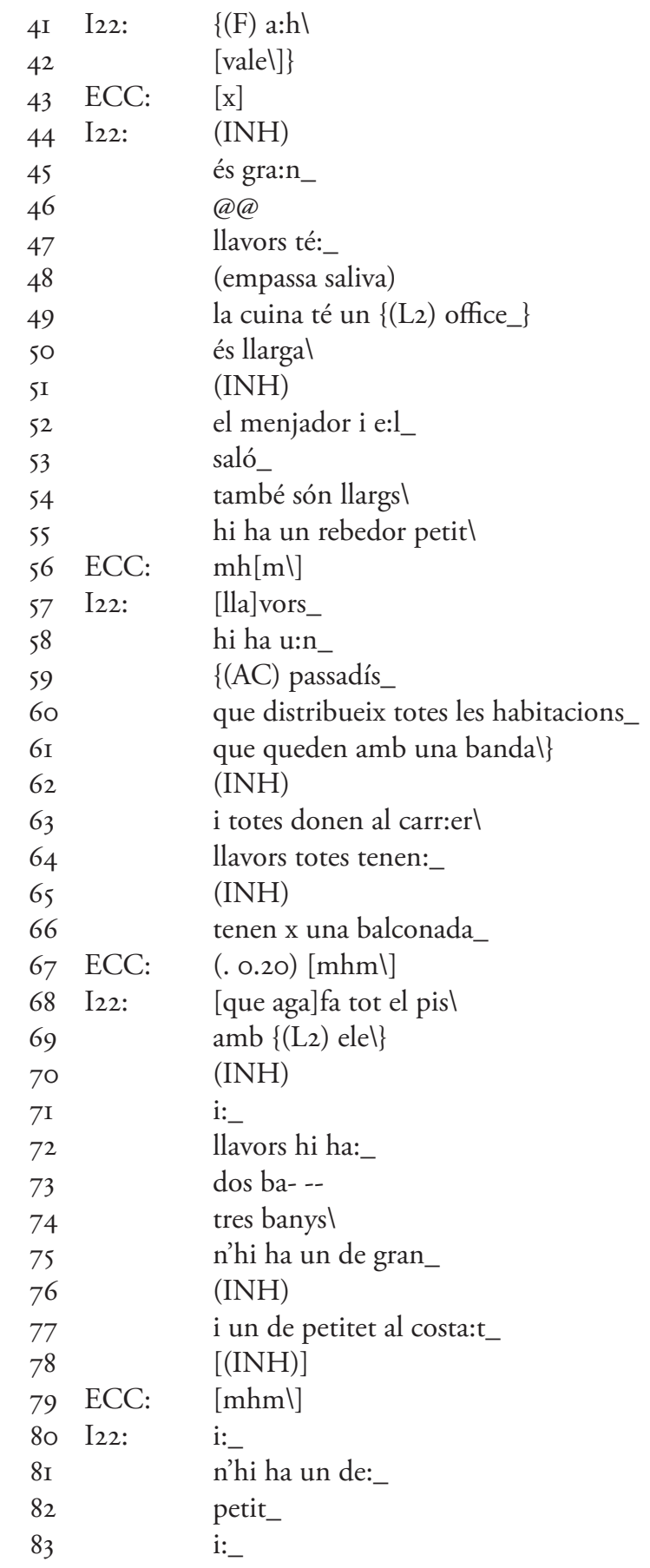




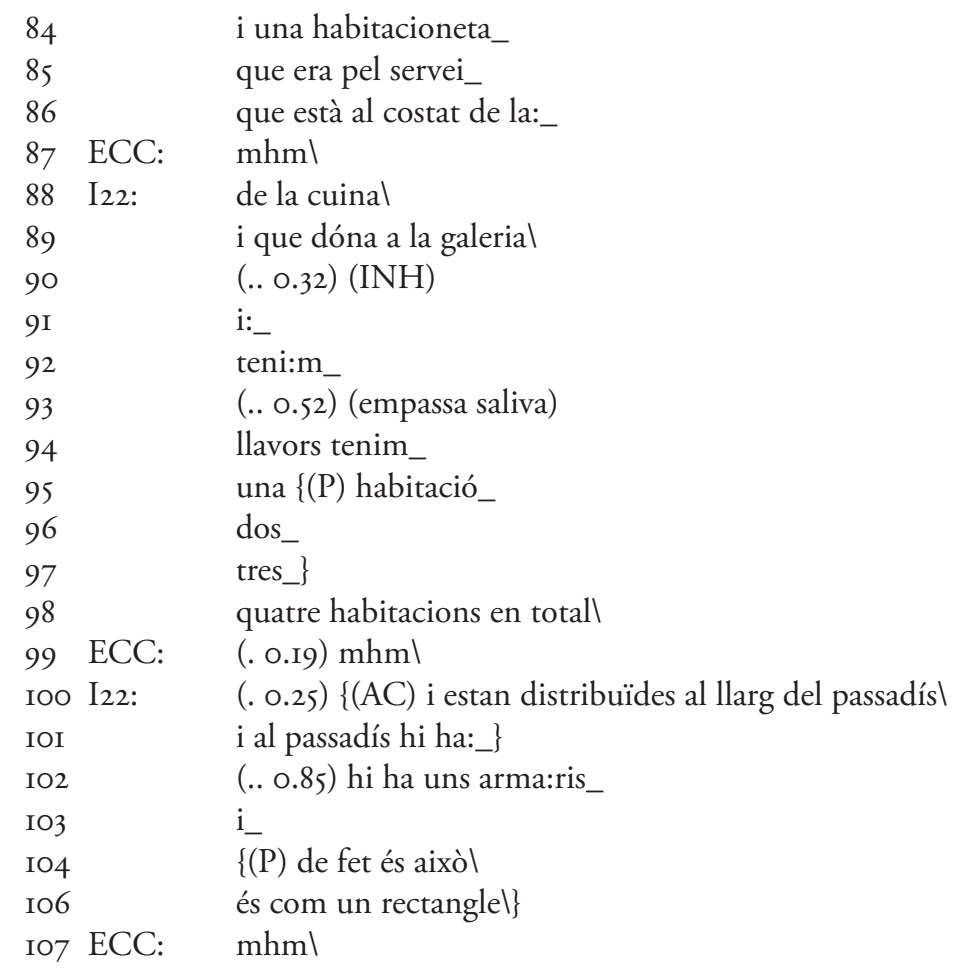

\subsubsection{Expository}

\section{CiCEorCC}

I IoI: do:ncs:

2. (... I.40) el divendres_

3 plego de treballar a les o:nze_

$4 \quad(. .0 .43) \mathrm{i} \mathrm{m:-}$

$5 \quad$ (.. 0.58) me'n vaig a prendre algol

6 ECC: $\quad(. .0 .30)[\{(\mathrm{P}) \mathrm{mhm} \mid\}]$

7 Ior: [però] també_

8 és que surto supercansada

9 perquè m’he aixecat a les set $\{(@)$ del dematí_\}

Io (.. o.6I) o sigui que:

II $\quad(. .0 .33)$ me'n vaig a dormi:r_

I2 (.. o.87) no sé_

I3 cap a les du:gues o aixíl

I4 (.. o.74) \{(AC) i el dissabte normalment em passo tot el dia al matí dormi:nt_\}

$15 \quad\left(\ldots\right.$ I.06) $\mathrm{i}_{-}$

I6 per la tarda me'n vaig:-- 


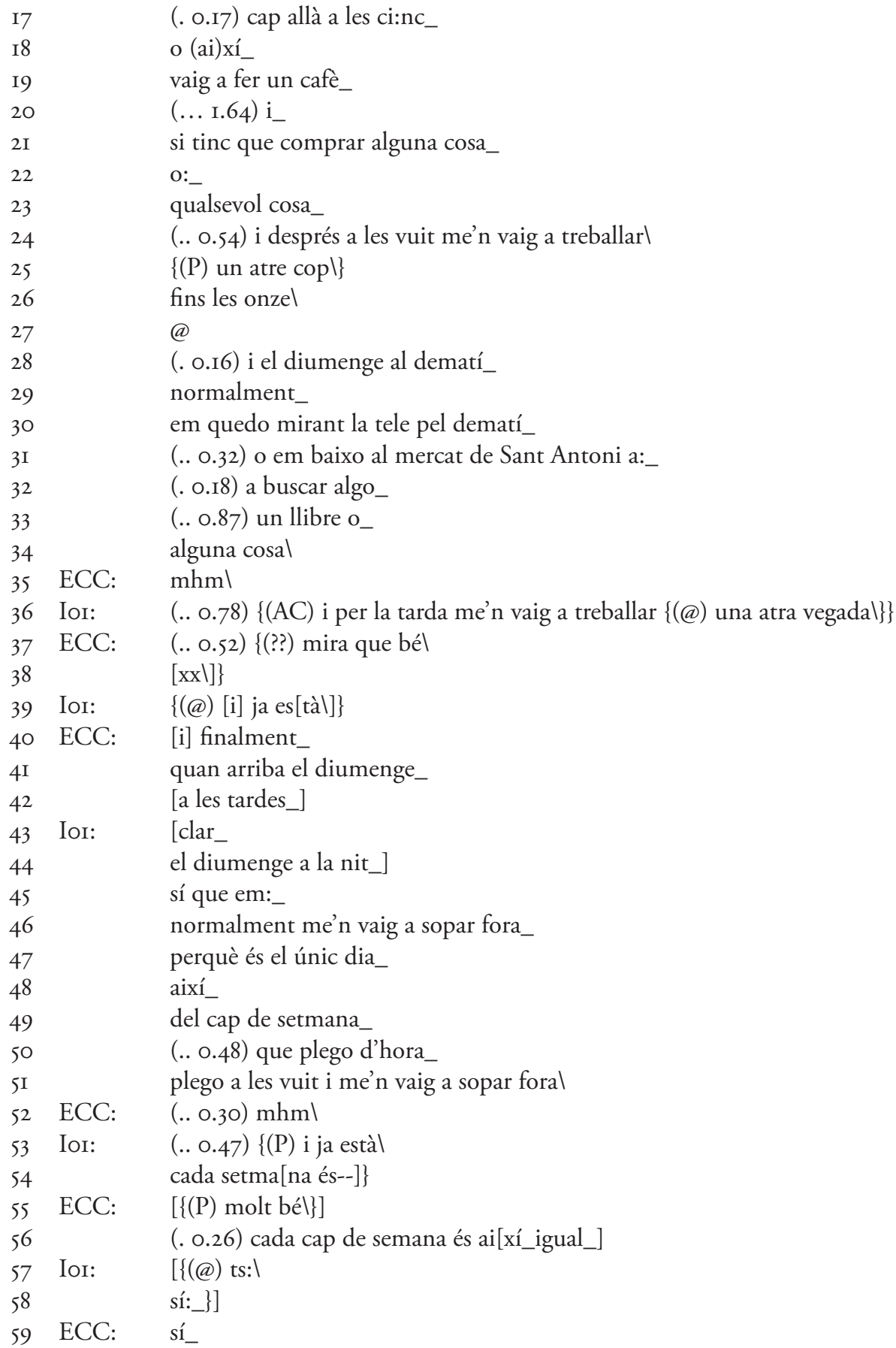




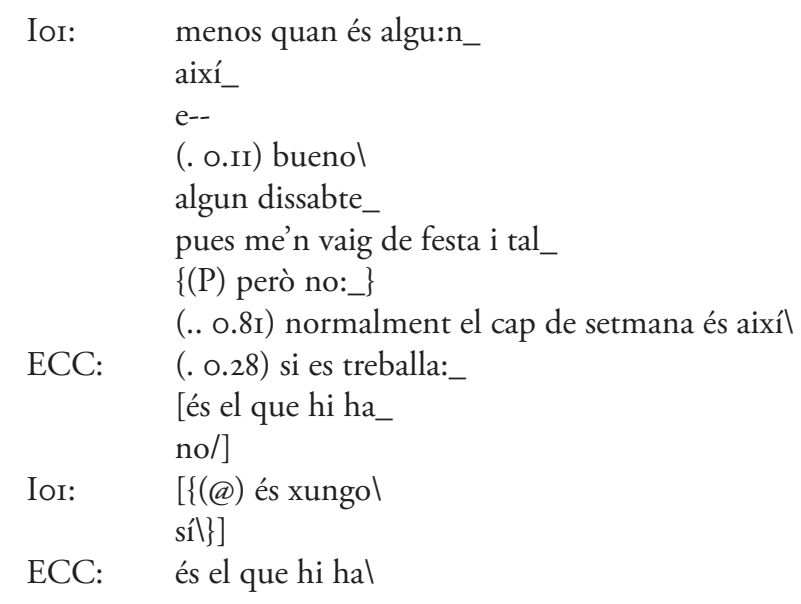

\subsubsection{Instructive}

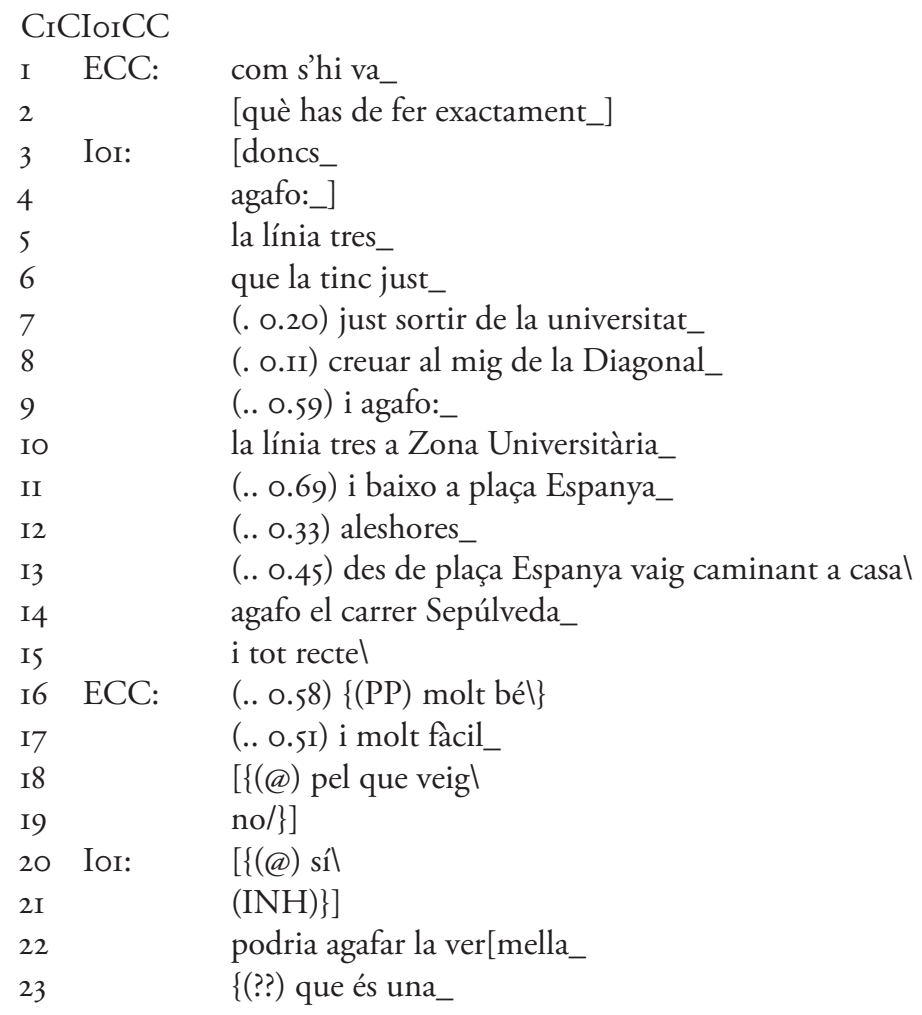




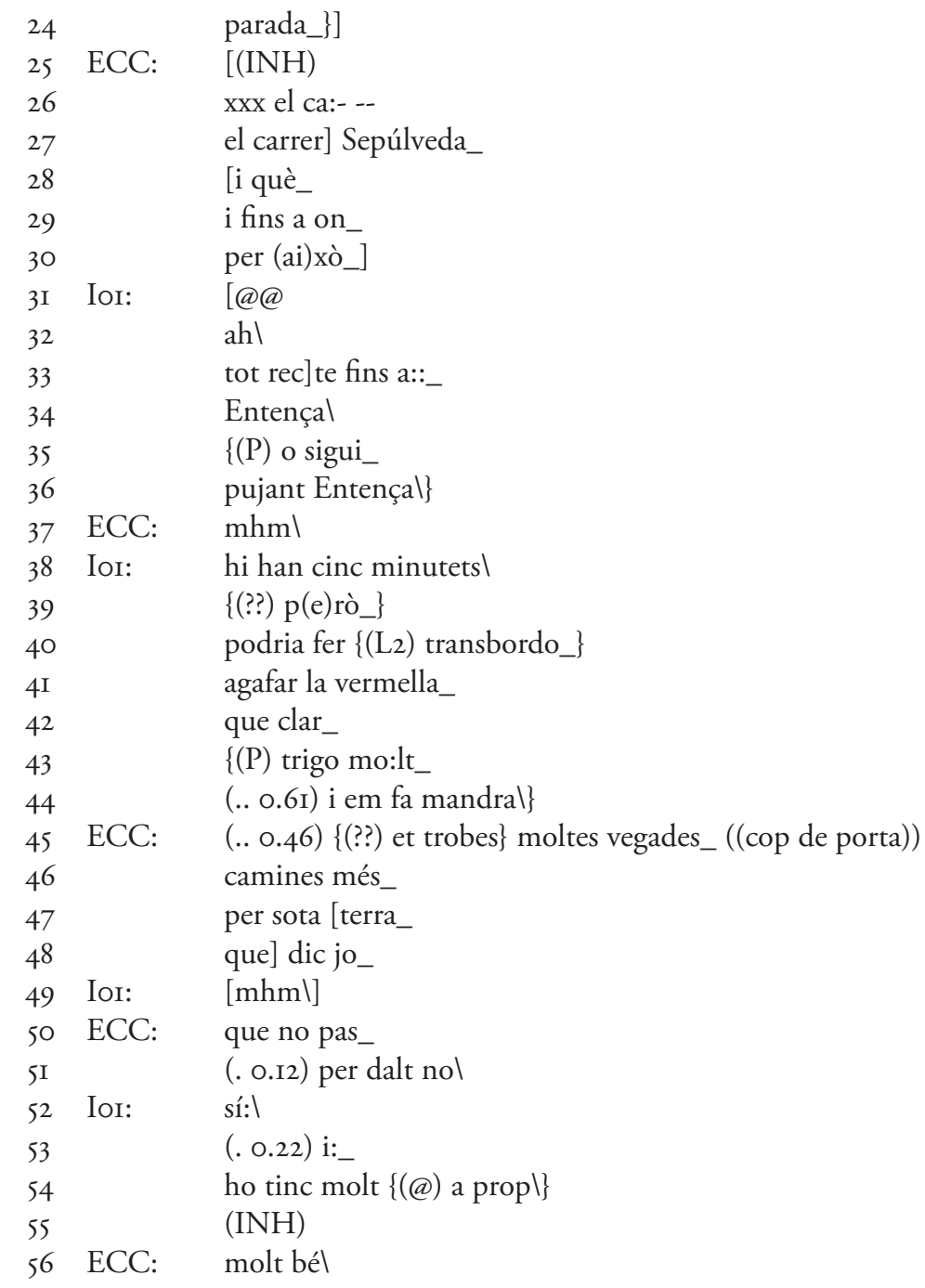

\subsubsection{Argumentative}

$\begin{array}{lll}\text { CiCAo4CC } & \\ \text { I } & \text { Io4: } & \text { do:ncs_ } \\ 2 & & \text { un llibrel } \\ 3 & \text { ECC: } & (. \text { o.20 }\{(\mathrm{P}) \text { molt bél\} } \\ 4 & \text { Io4: } & (. \text { o.27) el llibre es diu:_ } \\ 5 & & \text { L'Alquimista_ } \\ 6 & \text { ECC: } & [\{(\mathrm{P}) \text { mhm }\}\}]\end{array}$




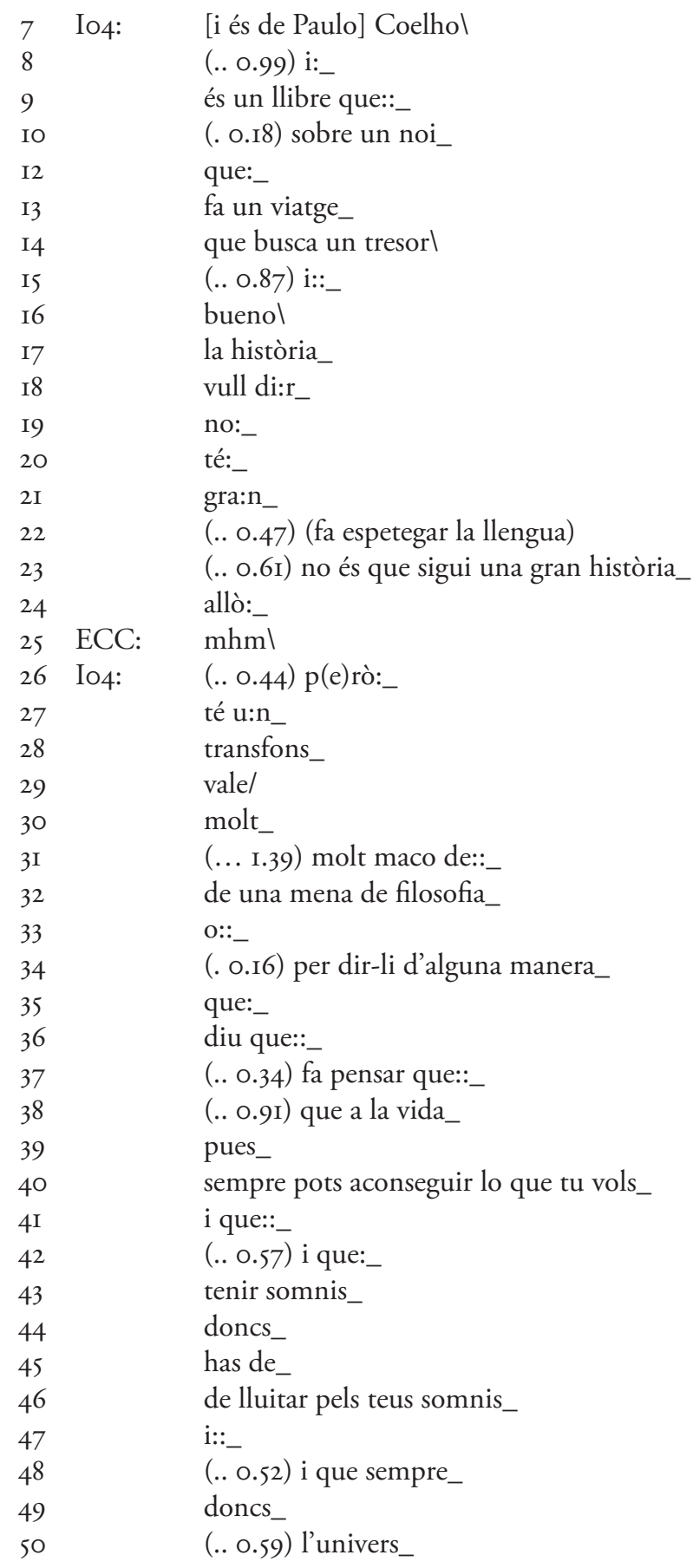




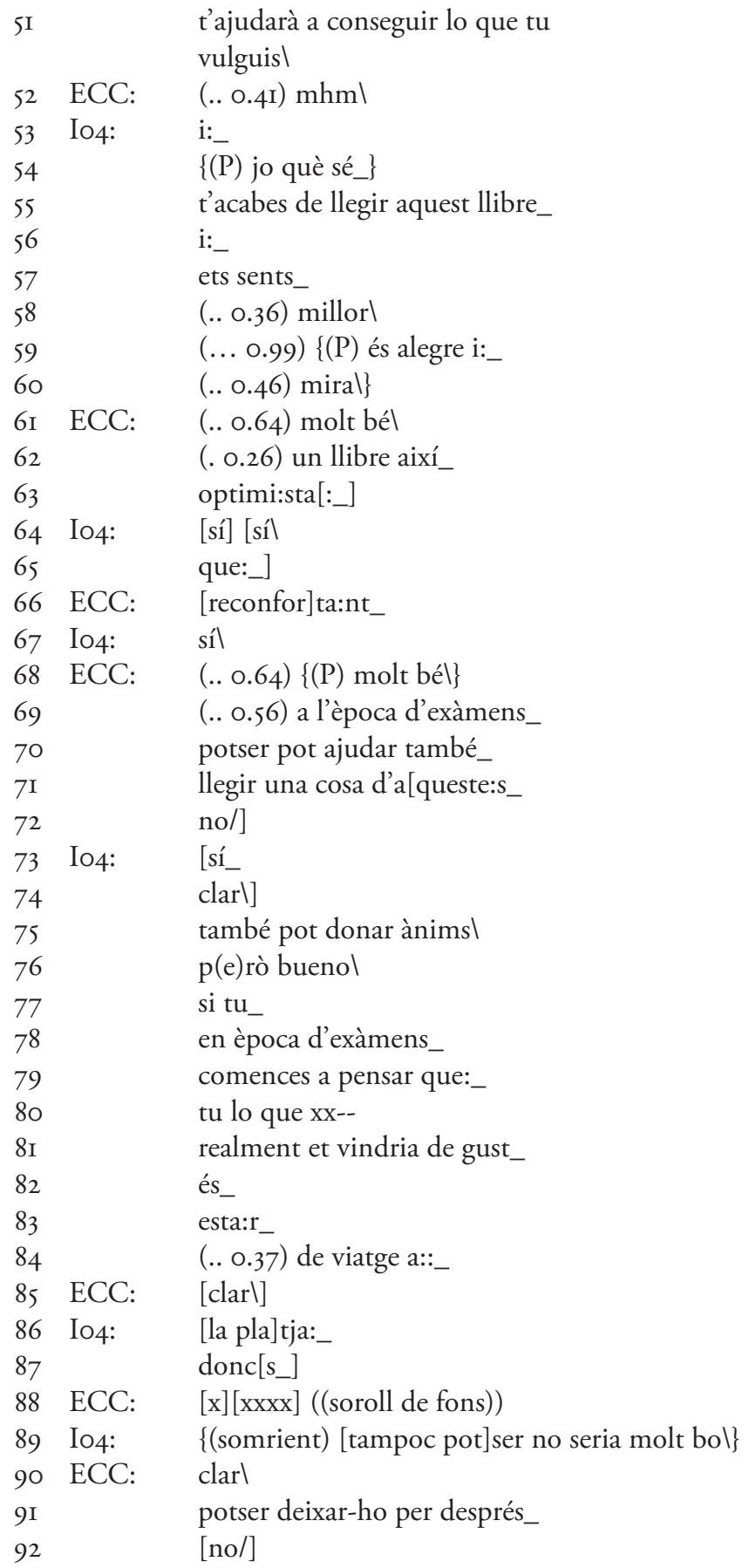


93 Io4: [síl]

94 ECC: (. o.29) molt bél

\section{CLOSURE. A LOOK BACK AND FORTH AT THE SEARCH BASED ON ORAL CORPORA IN CATALAN}

The Plurilingual Audiovisual Corpus (CAP) is the culmination of the project that began with the COC and COR corpora. It provides the first opportunity to analyze transcribed text and voice recordings together with the corresponding image, and therefore with several typical features of the multimodal communication that characterizes oral discourse. It also offers the first chance to study certain aspects of the Catalan spoken by the informants, together with phenomena related to their performancee of other languages (in particular, Spanish and English), taking into account the different types of text that the speakers usually construct: narrative, descriptive, expository, argumentative and instructive. In short, the CAP is best described as a multitextual, multimodal and multilingual corpus and we hope that these characteristics will foster progress in a field of research that has yet to be fully exploited.

In order to keep up with current debates on criteria for corpus construction (access, representativeness, marking, extension...), it is worth noting that the corpora presented here oriented towards qualitative research in pragmatics and discourse analysis (especially oral), without missing the possibility of quantifying data. The reason for such approach is that these are the work fields of the researchers who promoted the corpora, gathered under the heading GrEPAD (as stated in section 5).

Studies and discussions on the design of these corpora were born many years ago (see Payrató et al. 1996), with a title deliberately chosen to state the requirements and attributes of such collections and archives of texts, namely Corpus, corpora. ${ }^{9}$ In turn, the areas of interest and research are also rooted in references from the last century, and they build on studies such as Payratós (I988) seminal work on colloquial Catalan - among other's - which would lead to the COC, and on functional variation (Payrató 1998), the origin of the COR.

Later, analyses with a more markedly pragma-stylistic and multimodal orientation were also added to these trends (cf. Payrató 2003, 2018 and Payrató \& Nogué 20I3). Therefore, it is clear that the basic and general research carried out has always gone hand

9. This is the first volume — not by accident - of the so-called «Catalan Linguistic Collection» (see $<$ http://www.publicacions.ub.edu/articulos.aspx?modo=c\&fam=LINGÜÍSTICA CATALANA >).

Caplletra 69 (Tardor, 2020), p. 155-199 
Lluís Payrató \& Neus Nogué

The oral corpora in Catalan and research into casual Catalan:

the corpora of conversation and functional varieties of the CCCUB

in hand with the elaboration of specific corpora. This explains the decision-making process carried out in their constitution, as well as their qualitative nature. Obviously, it should not be drawn from this that the corpora cannot be further improved and enriched, and that different decisions could not have been taken, nor that the research could not have been conducted in some way else.

From the current perspective it is worth pointing out a couple of remarks. Firstly, we know, at least from Romero-Trillo (2008), that pragmatics and corpus linguistics (cf. Habert et al. 1997; Biber et al. 1998, and many others) are "doomed» to understand in many aspects and levels. Secondly, that current general pragmatics must include, alongside experimental pragmatics, increasingly developed (see Noveck \& Sperber 2004, inter alia), corpus pragmatics, as the journal Corpus Pragmatics has shown in a very clear way since 2017. Now all the old, aforementioned debates take on a new dimension, the relation between the concepts of theory, practice and application remaining the same.

The passing of the years also teaches us that corpora are useful when used. In fact, the three corpora described in this article have already been applied in several $\mathrm{Ph} . \mathrm{D}$. theses and other research projects. Texts from the COC were used in Castellà (200I and 2004), Bladas (2000, 2003, 2006, 2009), Oller (2000), Payrató (1998), Payrató (2003, 2010), Nogué (2005, 2008a, 2008b, 20I0), Matamala (2008), Cuenca \& Torres (2008), Bladas \& Nogué (2016), and De Cock \& Nogué (2017). The COR was used in Nogué (2005, 2008a), and the CAP in Fitó (2009) and Lloberes \& Payrató (20II). Additionally, all of these corpora have been used as data sources for multiple examples (see inter alia Payrató 2003, 2018).

Although Catalan still lacks an oral and written reference corpus providing comprehensive information about the language and allowing wide-ranging quantitative research, this study shows the value of the corpora presented here for conducting both quantitative and qualitative studies of many aspects of the structure and use of Catalan.

Lluís Payrató

Universitat de Barcelona

payrato@ub.edu

ORCID oooo-00oI-89I9-2886

Neus Nogué

Universitat de Barcelona

nnogue@ub.edu

ORCID 0000-0002-5671-310I 


\section{BIBLIOGRAPHIC REFERENCES}

Alturo, Núria, Òscar Bladas, Marta Payà \& Lluís Payrató, eds. (2004) Corpus oral de registres. Materials de treball, Barcelona, Publicacions de la Universitat de Barcelona.

Biber, Douglas, Susan Conrad \& Randi Reppen (1998) Corpus linguistics. Investigating language structure and use, Cambridge, Cambridge University Press.

BLADAS, Òscar (2000) «Les rutines de parla en el català col-loquial», in Vicent Salvador \& Adolf Piquer (eds.): El discurs prefabricat: estudis de fraseologia teòrica $i$ aplicada, Castelló de la Plana, Publicacions de la Universitat Jaume I, p. 325-33I.

- (2003) Les rutines de parla en el català col-loquial, Ph. D. thesis, Barcelona, Universitat de Barcelona.

- (2006) «Com dir el que no sona. Les rutines de parla en discurs directe periodístic i col.loquial», in Vicent Salvador \& Laia Climent (eds.), El discurs prefabricat II: Fraseologia i comunicació social, Castelló de la Plana, Universitat Jaume I, p. 267-30I.

- (2009) Manual de transcripció del discurs oral. Materials de treball. Barcelona: Universitat de Barcelona / PPU. [On line: <http://diposit.ub.edu/ dspace/ bitstream/2445/I0630I/I/Manual de transcripció.pdf>.]

Bladas, Òscar \& Neus Nogué (20I6) “"Que bé, tu!” (“That’s great, you”): an emerging emphatic use of the second person singular pronoun tu (you) in spoken Catalan», Pragmatics, 26, p. 473-500.

Boix-Fuster, Emili, Marina Àlamo, Mireia Galindo \& F. Xavier Vila (2006) Corpus de varietats socials. Materials de treball, Barcelona, Publicacions de la Universitat de Barcelona.

Castellà, Josep M. (200I) La complexitat lingüistica en el discurs oral i escrit: densitat lèxica, composició oracional i connexió textual, $\mathrm{Ph}$. D. thesis, Barcelona, Universitat de Barcelona.

- (2004) Oralitat i escriptura. Dues cares de la complexitat del llenguatge, Barcelona, Curial Edicions Catalanes / Publicacions de l'Abadia de Montserrat.

Cuenca, M. Josep (20II) «Catalan interjections», in Lluís Payrató \& Josep M. Cots (eds.), The Pragmatics of Catalan, Berlin/Boston, De Gruyter Mouton, p. I73-2II.

Cuenca, M. Josep \& Marta Torres (2008) «Usos de hombre/home y mujer/dona como marcadores del discurso en la conversación coloquial», Verba, 35, p. $235-256$.

De Cock, Barbara \& Neus Nogué (20I7) «The pragmatics of person reference: A comparative study of Catalan and Spanish parliamentary discourse», Languages in Contrast, I7, p. 96-I27. 
Lluís Payrató \& Neus Nogué

The oral corpora in Catalan and research into casual Catalan:

the corpora of conversation and functional varieties of the CCCUB

Du Bois, John W., Stephan Schuetze-Coburn, Susanna Cumming \& Danae PaOlino (1993) "Outline of discourse transcription», in Jane A. Edwards \& Martin D. Lampert (eds.), Talking data: Transcription and coding in discourse research, Hillsdale, Lawrence Erlbaum, p. 45-89.

Habert, Benoît, Adeline Nazarenko \& André Salem (1997) Les linguistiques de corpus, Paris, Colin - Masson.

Lloberes, Marina \& Lluís Payrató (2OII) «Pragmatic coherence as a multimodal feature: Illustrative cospeech gestures, events, and states», in Lluís Payrató \& Josep M. Cots (eds.), The Pragmatics of Catalan, Berlin/Boston, De Gruyter Mouton, p. 215-246.

Matamala, Anna (2008) «La oralidad en la ficción televisiva: análisis de las interjecciones de un corpus de comedias de situación originales y dobladas», in Jenny Brumme (ed.), La oralidad fingida: descripción y traducción, Madrid, Iberoamericana - Vervuert.

Nogué, Neus (2005) Dixi de persona i marcs participatius en català, Ph. D. Thesis, Barcelona, Universitat de Barcelona / Departament de Filologia Catalana.

- (2008a) La dixi depersona en català, Barcelona, Publicacions del'Abadia de Montserrat.

- (2008b) «La dixi de persona en el discurs acadèmic oral en català», Caplletra. Revista Internacional de Filologia, 44, p. 195-218.

- (20I0) «La primera persona del plural en català», Llengua \& Literatura, 2I, p. I55-I98.

Noveck, Ira A. \& Dan Sperber, eds. (2004) Experimental pragmatics, New York, Palgrave Macmillan.

Oller, Anna (2000) "Connectors i fraseologia: el llavors col-loquial», in Vicent Salvador \& Adolf Piquer (eds.), El discurs prefabricat: estudis de fraseologia teòrica $i$ aplicada, Castelló de la Plana, Publicacions de la Universitat Jaume I, p. 333-342.

Payrató, Lluís (1995) «Transcripción del discurso coloquial», in Luis Cortés (ed.), El español coloquial, Almería, Universidad de Almería, p. 45-70.

- (2003) Pragmàtica, discurs i llengua oral, Barcelona, UOC (2nd ed., 2010).

- (2018) Introducción a la pragmática. Una perspectiva sobre el lenguaje en acción, Madrid, Síntesis.

—, ed. (1998) Oralment. Estudis de variació funcional, Barcelona, Universitat de Barcelona / Publicacions de l'Abadia de Montserrat.

Payrató, Lluís \& Núria Alturo, eds. (2002) Corpus oral de conversa col-loquial. Materials de treball, Barcelona, Publicacions de la Universitat de Barcelona.

Payrató, Lluís, Emili Boix, M. Rosa Lloret \& Mercè Lorente, eds. (i996) Corpus, corpora, Barcelona, PPU / Universitat de Barcelona. 
Lluís Payrató \& Neus Nogué

The oral corpora in Catalan and research into casual Catalan: the corpora of conversation and functional varieties of the CCCUB

Payrató, Lluís \& Jaume Fitó, eds. (2008) Corpus audiovisual plurilingüe, Barcelona, Universitat de Barcelona.

Romero-Trillo, Jesús, ed. (2008) Pragmatics and corpus linguistics. A mutualistic entente, Berlin, Mouton de Gruyter.

Subirats, Marina, Marta Massats \& Cristina Sánchez (I992) «II. Els hàbits lingüístics», in Marina Subirats (dir.), Enquesta de la Regió Metropolitana de Barcelona I990, Barcelona, Institut d'Estudis Metropolitans de Barcelona. 